Volume 8 | Issue 1

$11-1-2020$

\title{
Scaling Commercial Law in Indian Country
}

MARC LANE ROARK

Southern University Law Center, mroark@sulc.edu

Follow this and additional works at: https://scholarship.law.tamu.edu/lawreview

Part of the Commercial Law Commons, Indian and Aboriginal Law Commons, and the Law and Economics Commons

\section{Recommended Citation}

MARC L. ROARK, Scaling Commercial Law in Indian Country, 8 Tex. A\&M L. Rev. 89 (2020).

Available at: https://doi.org/10.37419/LR.V8.I1.3

This Article is brought to you for free and open access by Texas A\&M Law Scholarship. It has been accepted for inclusion in Texas A\&M Law Review by an authorized editor of Texas A\&M Law Scholarship. For more information, please contact aretteen@law.tamu.edu. 


\title{
SCALING COMMERCIAL LAW IN INDIAN COUNTRY
}

\author{
by: Marc L. Roark*
}

\begin{abstract}
How do you drive economic enterprise in a financial desert? Indian tribes, academics, economists, and policy makers have considered the means and methods for energizing economic growth for forty years. Efforts such as the creation and promotion of the Model Tribal Secured Transactions Act ("MT$S T A$ ") promise much toward creating conditions that would gather financial opportunity to tribal regions that experience poverty at a strikingly higher rate than any other place in the United States. And yet, while the law has been available for more than ten years, tribes have been reticent to adopt it. This Article fills the vacuum in the literature around the promise of uniform laws in Indian Country by describing the inherent tension that exists between downscaling uniform laws into tribal contexts and the localism that seeks to preserve localized values. This Article argues that tribal choices to accept uniformity or reject uniformity in these areas are built around a combination of formal associations and organic relationships designed to create "institutional thickness" in the face of other scarce resources.
\end{abstract}

\section{Table of Contents}

I. IntRoduction .............................. 90

II. Secured Transactions in Indian Country ........ 96

A. Tribes That Have Incorporated the Local State UCC into Tribal Law ............................ 96

B. Tribes That Have Adopted the ULC Version of the UCC into Tribal Law ........................ 100

C. Tribes That Have Adopted Provisions of the UCC Relating to Sales of Accounts and Chattel Paper....

D. Tribes That Have Adopted the MTSTA or the RMTSTA into Tribal Law.......................

E. Tribes That Have Adopted a Non-Uniform Secured Transactions Law .............................

DOI: https://doi.org/10.37419/LR.V8.I1.3

* Louisiana Outside Counsel of Health and Ethics Professor of Law and Senior Fellow, Native American Law and Policy Institute, Southern University Law Center. Many thanks go to William Henning, Christopher Odinet, Donna Feir, Christian Dippel, Bryan Leonard, Bob Miller, Ezra Rosser, and Stephen Ware for comments on draft versions of this Article. This Article was presented at the Hoover Institute's workshop on Indigenous Economies in November 2019 and benefited from the thoughtful comments and suggestions from participants there. I would also like to thank Sahara Fletcher (L'21), Alexandra LeBlanc (L'22), and Maylan Cruickshanks (L'23) for their assistance in gathering information on tribes early in the process. Funding to support this Article was provided by Southern University Law Center with special thanks to Chancellor John K. Pierre. The Louisiana Outside Counsel of Health and Ethics Professorship is made available through the State of Louisiana Board of Regents Support Fund. 
F. Tribal Approaches to Filing Systems ............ 105

III. Scaling Economic Relationships and Tribal

Sovereignty in Commercial LaW ............... 111

A. Scaling Secured Transactions Laws in Indian

Country ................................ 112

1. Downscaling Uniform Law in Indian Country .. 112

2. Localizing Commercial Law Efforts on Indian

Tribes .................................. 113

B. Relational Structures Through Commercial Law .... 115

1. Formal Relationships ..................... 121

a. Manufacturing Institutional "Thickness"

Through Compacts with States........... 122

b. Waivers of Sovereign Immunity Relating to

Commercial Claims ....................... 124

2. Organic Relationships .................... 125

IV. Conclusion ................................. 128

\section{INTRODUCTION}

In the last twenty years, economic activity in Indian tribes has fostered a greater interest in creating and facilitating resources that trickle down to tribal members. The unique place of tribes as separate sovereigns has opened up opportunities in gaming, ${ }^{1}$ natural resources, ${ }^{2}$ smoke shops ${ }^{3}$ and similar opportunities to exploit gaps in the market that make their services either financially more attractive ${ }^{4}$ or-such as in the case of gaming - available in regions where similar services are not possible. ${ }^{5}$ Yet, despite the favorable market conditions that Indian tribes experience due to their status as separate sovereigns, the payoff of economic growth has been uneven. Indeed, some tribes that operate in these sectors have only experienced marginal economic growth (or none at all), ${ }^{6}$ while others have used the sudden increase in economic resources for social improvement. ${ }^{7}$ As Ezra

1. Richard J. Ansson, Jr. \& Ladine Oravetz, Tribal Economic Development: What Challenges Lie Ahead for Tribal Nations as They Continue to Strive for Economic Diversity?, 11 Kan. J.L. \& Pub. Pol'y 441, 446-48 (2001); Alan P. Meister, Kathryn R. L. Rand \& Steven Andrew Light, Indian Gaming and Beyond: Tribal Economic Development and Diversification, 54 S.D. L. REv. 375, 375-76 (2009).

2. Steven J. Shupe, Indian Tribes in the Water Marketing Arena, 15 Am. Indian L. REv. 185, 186-90 (1990).

3. Ansson \& Oravetz, supra note 1 , at 445.

4. See Matthew L. M. Fletcher, In Pursuit of Tribal Economic Development as a Substitute for Reservation Tax Revenue, 80 N.D. L. Rev. 759, 787-88 (2004). See generally Judith Resnik, Dependent Sovereigns: Indian Tribes, States, and the Federal Courts, 56 U. CHI. L. Rev. 671 (1989); Patrice H. Kunesh, Tribal Self-Determination in the Age of Scarcity, 54 S.D. L. Rev. 398, 398-418 (2009).

5. Kenneth W. Grant II, Katherine A. Spilde \& Jonathan B. Taylor, Social and Economic Consequences of Indian Gaming in Oklahoma, 28 Aм. Indian Culture \& REs. J. 97, 107-13 (2004).

6. Ansson \& Oravetz, supra note 1, at 441.

7. Grant et al., supra note 5, at 110-13. 
Rosser eloquently describes, these economic conditions are not merely abstract but rather have life and death implications for tribal members: "Indians living on reservations are poorer than any other group in the United States, and this poverty is felt in everything from the prevalence of substandard housing and lack of basic infrastructure to shortened lifespans and high suicide rates."

Significant structural barriers are often the root problem of slow economic growth on Indian tribes, despite the presence of favorable conditions. For example, Robert Miller has pointed to how structural barriers, such as federal policies relating to Indian tribal governance or the lack of focus on economic development by tribes, ${ }^{9}$ have stymied economic sectors otherwise poised for significant economic expansion. ${ }^{10}$ The lack of capital opportunities in Indian territory has been traced to not only high unemployment rates but also to economic leakage - the rate that cash flows out of a region once it enters the market place. ${ }^{11}$ Leakage can be contrasted to reinvestment where dollars spent recirculate through regions. ${ }^{12}$

In recent years, the Uniform Law Commission ("ULC") has facilitated a major effort to address structural gaps in Indian Country lending resources. The Model Tribal Secured Transactions Act ("MTSTA") and its successor, the Revised Model Tribal Secured Transactions Act ("R-MTSTA"), have attempted to facilitate access to capital on Indian reservations by facilitating familiar laws for lenders in relation to chattel and personal property security. Nevertheless, while the adoption of uniform tribal laws sets the conditions for potential growth for Indian tribes, it does not alleviate other structural barriers that may exist which continue to thwart economic activity. Indeed, the experience of the MTSTA and R-MTSTA suggests that significant structural barriers exist that may impact either the adoption of these laws or the effectiveness of them once adopted. ${ }^{13} \mathrm{Se}$ cured transactions laws can be found on only 62 tribes out of the 573 (2014)

8. Ezra Rosser, Creating Space for Reservation Growth, 9 FIU L. REv. 351, 351

9. Robert J. Miller, Reservation “Capitalism”: Economic Development In Indian COUnTRY (2012).

10. Robert J. Miller, Economic Development in Indian Country: Will Capitalism or Socialism Succeed?, 80 Or. L. Rev. 757, 851-52 (2001).

11. Miller, supra note 9, at 66-67.

12. Gavin Clarkson, Tribal Finance and Economic Development: The Fight Against Economic Leakage, in AmericAn Indian Business 82-88 (Deanna M. Kennedy et al. eds., 2017) (noting the challenges that lack of secure financing presents leading to loss of economic resources to nearby towns that are off reservation).

13. William H. Henning, Susan M. Woodrow \& Marek Dubovec, $A$ Proposal for a National Tribally Owned Lien Filing System to Support Access to Capital in Indian Country, 18 WyO. L. REv. 475, 486-89 (2018). 
federally recognized tribes. ${ }^{14}$ This is highlighted by the presence of "credit deserts" in areas where Indian tribes are found. ${ }^{15}$

These two structural problems are not unrelated. The lack of familiar, cost-saving creditor laws is one (but not the only) reason for the lack of traditional lending enterprises in tribal regions. The geographic distance between the center of a tribal community and its access to reliable forms of credit is directly tied to the conditions that would otherwise lead to capital growth for Indian tribes. ${ }^{16}$ This Article unpacks the means and effect for how tribes have adopted secured transactions laws, drawing on the concept of scale, to describe how the theory and process of uniformity (a downscaling effect) can lose effectiveness when tribes deviate from uniform approaches.

At a fundamental level, scale is a concept of measurement and comparison. ${ }^{17}$ Applied to physical assets or operations, the term "scalability" refers to the ability to expand an existing concept or organization without changing the frames that supported it in the first place. ${ }^{18}$ A project or concept that can be "scaled up" is one that can be expanded beyond its natural parameters without changing the premise on which it was based. Scalability is not an "ordinary feature of nature"; 19 making projects "scalable" requires significant work and still, some features of the expansion may be "unscalable." 20

Law itself is a scaled exercise, inasmuch as it seeks to define problems or conflicts in relation to individuals and things, applying frames, rules, principles, and norms to mitigate the complexities that the infinite variety of human interaction and social life produces. ${ }^{21}$ Scale can be applied to measure size, relationships, and hierarchies.

14. See infra Appendix (offering a comprehensive catalogue of tribal adoptions).

15. Tristan Ahtone, Native-Owned Financial Institutions Battle Credit Deserts, High Country News (Oct. 16, 2018), https://www.hcn.org/articles/tribal-affairs-na tive-owned-financial-institutions-battle-credit-deserts [https://perma.cc/5682-DBS7]; Ronald A. Wirtz, Breaching the "Buckskin Curtain”, Fed. Res. Bank Minneapolis (Sept. 1, 2000), https://www.minneapolisfed.org/article/2000/breaching-the-buckskincurtain [https://perma.cc/VVE4-M4UW].

16. Ahtone, supra note 15 ("When we ask if we are meeting the credit and capital needs of Indian Country, we will measure the distance between the community and the nearest bank.").

17. Anna Lowenhaupt Tsing, Some Problems with Scale, in The Mushroom At THE END OF THE WORLD 37-38 (2015).

18. $I d$. at 38 .

19. Id. at 43 .

20. Sometimes, legal regimes can be replicated across different settings without rendering imposing greater costs on the legal setting. But mostly, because legal problems arise in context-specific settings, they often require significant effort to effectuate the same results at a different scale than the one the regime was designed for. In contrast, the UCC has been the exception to the rule, often fitting across regimes.

21. See Cary Wu, Rima Wilkes, Daniel Silver \& Terry Nichols Clark, Current Debates in Urban Theory from a Scale Perspective: Introducing a Scenes Approach, 2018 URB. STUD. 1, 2 (2018) (noting that dialectal scale is scale relating to relationships); Hari Osofsky, The Geography of Justice Wormholes: Dilemmas from Property and Criminal Law, 53 Vill. L. Rev. 117, 147 (2008). 
For example, commercial law reduces the complexity of local problems creating structures and frameworks that define relationships among actors; the fact that commercial law happens at both a local level (small) and a national or international level (large) invokes a comparison of size. Secured transactions laws establish both relationships and hierarchies between creditors and debtors. By determining how creditors may create a security interest through the process of "attachment," 22 the law defines when a relationship is governed by the secured transactions law. ${ }^{23}$ Ordering those claims through a process of perfection and filing establishes a hierarchy of how creditors may assert claims against the personal property of debtors. ${ }^{24}$ Commercial law then can be understood as a production of the state in that it manufactures these relationships and hierarchies to frame and resolve collective problems, such as uncertainty that arises from dissimilar approaches to securing collateral. ${ }^{25}$ Like the Fordist factory that scales its application across a manufacturing state, law seeks to simplify conflicts by framing these through high-level principles and established rules.

Uniformity is an exercise in applying legally scaled projects in distinct contexts. When governments adopt uniform laws (whether states or tribes) they engage in a downscaling of one of the conditions that

22. Attachment is the creation of a security interest by a debtor in favor of a creditor in which an interest in some property is associated to the debt obligation. Under the UCC, the basic requirements for attachment are that the debtor have "rights in the collateral," that value be given to support the creation of the security interest, and that the transaction have the indicia that suggests that the debtor intends to be bound by the contract. See U.C.C. § 9-203 (Am. LAw Inst. \& Unif. Law Comm'N 2020). This version of attachment is replicated in the MTSTA and the R-MTSTA. See MTSTA § 9-202(b); R-MTSTA § 9-202.

23. The law creates different relationships by defining individuals, things, and transactions. One of the powers of the law is to weigh those relationships against one another-known as Dialectical Scale.

24. One of the important functions of secured transactions is to determine priority amongst competing creditors. The body of law then is built to determine not only the effectiveness of security interests, but their hierarchy. Scaled hierarchies are "the effects of efforts to sort, group, and categorize many things, people, and qualities in terms of relative degrees of elevation or centrality." See E. Summerson Carr \& Michael Lempert, Introduction: Pragmatics of Scale, in SCAlE: Discourse AND Dimensions of Social Life 3 (E. Summerson Carr \& Michael Lempert eds., 2016).

25. James Scott defines this as a process of making problems more legible. JAMES C. Scott, Seeing Like a State: How Certain Schemes to Improve the Human Condition Have Failed 3 (Nachdr. ed., 2008). Thus, just as states used maps to make tax collection more efficient and adopted official languages to make government bureaucracy accessible, law adopts approaches that seek to reduce problems into solvable units. $I d$. Property law's reliance on entitlements as a starting point for understanding how and when entitlements shift helps courts and law makers understand how the property system operates. Guido Calabresi \& A. Douglas Melamed, Property Rules, Liability Rules, and Inalienability: One View of the Cathedral, 85 Harv. L. Rev. 1089, 1090 (1972). 
furthers economic growth and vitality. ${ }^{26}$ The process of creating and adopting uniform law is taking a unit developed for one setting and fitting it to larger or smaller contexts. Adopting uniform laws on Indian tribes downscales the law by reshaping it around the local context. Uniformity in commercial law has long been regarded as a key path toward reducing potential uncertainties that increase the costs of conflict in commercial settings. Uniformity's advantage has always been toward avoiding the alternative of "scattered court decisions or un-litigated traditions" 27 in favor of a coherent set of principles that parties can rely on in their commercial dealings. The process of uniformity involves a mix of stakeholders and legal experts who are tasked with finding room for agreement that the law can be accepted uniformly. ${ }^{28}$

The intended result of uniformity is to elevate what would be purely local transactions to a broader, more regional effect. ${ }^{29}$ Commercial law's downscaling of uniform law to local practice in turn upscales individual transactions to a broader network of commercial resources. Thus, transactions are not purely "local" but rather enjoy access to a stream of commerce that networks financial resources across localities, regions, and even nations. Transactions embolden the power of the dollar by giving it currency in the local region, empowering greater economic growth through collective resourcing, and reducing the leakage that occurs when money has nowhere to go. In short, when governments (both states and tribes) deviate from expected patterns of business and trade that firms have come to rely on, they hinder the expansion of opportunities that require outside resources that purely local regions cannot deliver on.

That does not mean that either scaling (upscaling or downscaling legal regimes) or localizing economic norms are de facto rational or irrational decisions. In fact, because scale-making is inherently relational and comparative, it "always entails drawing distinctions" based on how choices impact other costs and gains. ${ }^{30}$ Scale-making often "conflat[es] what is geographically, geopolitically, temporally, or morally 'near' while simultaneously distinguishing the qualities of near-

26. Truman Carter \& Fred H. Miller, Uniform Laws and Tribal Legislation; One Tribe's Perspective, 26 Am. Indian L. Rev. 89, 89-104 (2001).

27. Raymond T. Nimmer, Uniform Codification of Commercial Contract Law, 18 Rutgers Comput. \& TeCH. L.J. 465, 465 (1992).

28. See, e.g., Neil B. Cohen \& Barry L. Zaretsky, Drafting Commercial Law for the New Millenium: Will the Current Process Suffice?, 26 Loy. L.A. L. Rev. 551, 555 (1992); Gail Hillebrand, What's Wrong with the Uniform Law Process?, 52 Hastings L.J. 631, 634 (2000); K. King Burnett, The Uniform Conservation Easement Act: Reflections of a Member of the Drafting Committee, 33 Utah Env'T L. Rev. 87, 87 (2013); James J. Brudney, The Uniform State Law Process, 8 Disp. Resol. Mag. 3,3 (2002).

29. See Carter \& Miller, supra note 26, at 104.

30. E. Summerson Carr \& Michael Lempert, Introduction: Pragmatics of Scale, in SCAlE 3 (E. Summerson Carr \& Michael Lempert eds., 2016). 
ness from that which is 'far." 31 Said a different way, uniform laws may appear either rhetorically near because they promise to facilitate greater economic expansion in concert with regional economic actors (including other states and tribes); or they may appear rhetorically too far, straining the tribe's view of self-sufficiency, sovereignty, and governance. When efforts to stimulate economic growth appear too far, tribes may assert localism factors that reshape the regime to the tribe's particular vision for self-determinacy. In this way, a legal geography approach can be useful for explaining how tribes have approached the ULC's MTSTA and other secured transactions laws.

Indeed, since the ULC released the MTSTA, only thirteen tribes have adopted it as the basis for establishing security over personal property, though several others have considered its implementation over the years. ${ }^{32}$ While the MTSTA's reception has been light, secured transactions laws of some variety have been adopted by more than sixty tribes. Most of these laws are based on uniform approaches to Secured Transactions in the sense that they derive from either the Uniform Commercial Code's ("UCC") Article 9 or the MTSTA. ${ }^{33}$ Yet, deviations still emerge in the implementation of the law. While the law has been adopted by these tribes in different regions, its implementation has been uneven. Some tribes have partnered with their local state secretary of state offices to contract for filing systems, while others have not set up local filing options. Even still, some tribal officers in tribes where the MTSTA or R-MTSTA were passed are unaware of the new laws, their purposes, or what they effect.

In Part I of this Article, I describe the adoption of secured transactions laws in Indian Country. Looking to the form and the substance of what tribes have adopted, I catalogue the different tribal laws in five distinct approaches to secured transactions laws: incorporation of state UCC provisions, adoption and modification of the ULC version of Article 9, adoption of provisions of the ULC version of Article 9 in limited contexts, adoption of the MTSTA, and non-uniform approaches to secured transactions. Additionally, in this part I catalogue how tribes that have adopted a secured transactions law have dealt with filing systems - an equally non-uniform collection of approaches.

In Part II of this Article, I begin to unpack some of the impacts that scaling and scale-making have in the context of these laws. In this Part, I point to various ways that tribes seek to further their economic interests, including such methods as uniformity, relationship creation, and networking. Likewise, I show how tribes impose localism over uniform approaches, limiting the potential gains that uniform law can provide. These efforts to localize economic interests include non-uniform approaches, limiting the types of transactions susceptible to uni-

31. Id.

32. See infra Appendix.

33. See infra Appendix. 
form approaches, limiting the actors who can take advantage of the tribal laws, and maintaining their own filing system. These modifications reduce both the network potential and the downscaling potential that uniformity offers. Drawing on economic geography, I argue that some of the choices that tribes make in this context are inherently relational, embedded in either formal associations or organic associations on tribal lands. Applying an economic geography approach to how the adoption of commercially friendly laws interact with tribal well-being is a new approach to both commercial law studies and Indian economic studies. ${ }^{34}$ This approach offers unique opportunities to better understand barriers of receptivity experienced by Indian communities toward commercial law adoptions.

\section{Secured Transactions in Indian Country}

Currently, sixty-two Indian tribes have a secured transactions law. These laws fit into one of five broad categories: (1) tribes that have incorporated the UCC adopted by the state where they are located (or in close regional proximity to their tribal territory); (2) tribes that have adopted the ULC version of the UCC; (3) tribes that have adopted the MTSTA; (4) tribes that have adopted uniform provisions relating to the sales of accounts or chattel paper; or (5) tribes that have adopted a non-uniform law governing the creation of security interests within their tribal territories. In addition to these different modes of adopting secured transactions laws, there is a distinction in some legislation about what entities have access to the tribal laws on secured transactions - some legislation is adopted only for the benefit of the tribe or other tribal enterprises, while some legislation does not designate a class of persons for whom the law is designed to facilitate secured lending.

Additionally, the variations for how tribes have structured their filing systems is as varied as the laws themselves. Some tribes have opted to maintain their own recording system within the confines of either a tribal court or some other tribal administrative office. Others have opted to utilize the local (geographically proximate) filing system of the state in which their territory is located. And finally, some tribes have created compacts with those states for the purposes of maintaining tribal filings. In this part, I depict what secured transactions laws have been adopted and their nuances and variations.

\section{A. Tribes That Have Incorporated the Local State UCC into Tribal Law}

Incorporating the local state UCC has its advantages for tribes seeking to provide a clear sense of continuity between the commercial

34. See Andy Pike \& Jane Pollard, Economic Geographies of Financialization, 86 Econ. Geography 29, 37-39 (2010). 
law surrounding tribal regions and the commercial law of the tribe. The earliest incorporation of a state's UCC provisions was by the Lummi Reservation in Washington in 1985. ${ }^{35}$ Other tribes that have incorporated their local state UCC include: the Bay Mills Indian Community (Michigan, 1994), ${ }^{36}$ the Chehalis Tribe, (Washington, 1995), ${ }^{37}$ the Fort Berthold Reservation (North Dakota, 2007), ${ }^{38}$ The Grand Traverse Band of Ottawa and Chippewa Indians (Michigan, 1999), ${ }^{39}$ the Ho-Chunk Nation (Wisconsin, 2004), ${ }^{40}$ the Kickapoo Traditional Tribe of Texas (2012), ${ }^{41}$ the Lac Courte Oreilles Band of Lake Superior Chippewa (Wisconsin, 2010) ${ }^{42}$ Little River Band of Ottawa Indi-

35. See 26 Lummi Nation Code of Laws § 26.03.010 (2016), https://narf.org/nill/ codes/lummi/26Commercial.pdf [https://perma.cc/9H54-LU95]. The adoption is nonuniform as it incorporates several amendments to the Washington UCC that apply on the Lummi Reservation. Particularly, the Lummi Reservation excludes certain tribal practices, such as gathering driftwood, fishing, and taking shellfish, from the commercial code, $i d$., and prohibits self-help remedies, $i d$. $\S 26.03 .090$.

36. See Secured Transactions Ordinance of Bay Mills Indian CommuNITY $§ 1$ (1994), http://www.baymills.org/resources/Secured\%20transactions\%20ordi nance.pdf [https://perma.cc/37MV-BEJR]. On November 15, 1994, the Bay Mills Indian Community adopted a Secured Transactions Ordinance that authorized the tribe or its entities to create secured transactions in tribal property. See Memorandum from Anne E. Bolton, Superintendent, Bureau of Indian Affairs, to Area Director, Minneapolis Area Office (Nov. 15, 1994) (on file with Author).

37. See 9 Chehalis Tribe Code $\$ 9.25 .010$ (1995) (on file with Author). It appears that the tribe may have had an earlier version of Article 9 identified as Prior Code $\$$ 6.1.1.030. The tribal code has been amended from time to time, including in 2007, 2015, and 2016. The code is limited to tribal transactions relating to tribal property.

38. On December 17, 2007, the Fort Berthold Tribal Business Council approved the adoption of the Three Affiliated Tribes of The Fort Berthold Reservation Secured Transactions Ordinance. See Three Affiliated Tribes, Special Meeting \#07-57-VJB (2007), https://static1.squarespace.com/static/5a5fab0832601e33d9f68fde/t/5b31e196f 950b7cb65f97fec/1529995672478/2007-12-17+TBC+Minutes+Without+Closed+Ses sion+Unapproved.pdf [https://perma.cc/6V4V-XX3N].

39. On May 12, 1998, the Grand Traverse Band of Ottawa and Chippewa Indians adopted a Secured Transactions Ordinance, and that Ordinance was amended on January 16, 1999. GTB Secured Transactions Ordinance, enacted by Tribal Council on May 12, 1998 (amended by Tribal Act \#98-16.668, enacted by Tribal Council on January 16, 1999). The ordinance incorporates the UCC law in effect and expressly designated by the parties, and if no law is designated, the UCC as enacted by state law according to the conflicts of law principles identified in the UCC. See 15 Grand Traverse Band of Ottawa and Chippewa Indians Tribal Code § 104(a) (2012), https://narf.org/nill/codes/grand_traverse/Title_15.pdf [https://perma.cc/YA4C4URK].

40. See Legislative Resolution 9/8/04C (Sept. 8, 2004) (adopting an ordinance incorporating the UCC as adopted in the State of Wisconsin into its tribal code). The ordinance was amended on May 5, 2005. See 5 Ho-Chunk Nation Tribal Code $§ 7$ (2005), https://ho-chunknation.com/wp-content/uploads/2019/10/5HCC7UniformCommercial-Code-Ordinance-05.05.05.pdf [https://perma.cc/CX88-9HE5].

41. See 25 Kickapoo Traditional Tribe of Texas Code $\$ 1$ (2012) (on file with Author). The tribal law is enacted as Chapter 25 of the Kickapoo Tribal Code. Id.

42. See 12 Lac Courte Oreilles Band of Lake Superior Chippewa Indians Tribal Code $\S 16-21$ (2010) (on file with Author). The Tribal Code incorporated the Wisconsin version of the UCC with certain non-uniform inclusions relating to filing, Tribal UCC $9 \S 2.1001 .501$; notification to creditors for disposition of collateral, id. 
ans (Michigan, 2004), ${ }^{43}$ the Little Traverse Bay Bands of Odawa (Michigan, 2005), ${ }^{44}$ the Mashantucket Pequot Tribe (Connecticut, $2008),{ }^{45}$ the Mille Lacs Band of Chippewa (Minnesota, 2014), ${ }^{46}$ the Mohegan Tribe (Connecticut, 1995), ${ }^{47}$ the Nottawaseppi Huron Band of the Potawatomi (Michigan, 2008), ${ }^{48}$ the Pascua Yaqui Reservation (Arizona, 2010) ${ }^{49}$ the Pokagon Band of Potawatomi Indians (Michigan, 2005), ${ }^{50}$ the Ponca Tribe (Iowa, 2009),${ }^{51}$ the Red Cliff Band of

$\$ 2.1001 .612$; limitations on the ability of creditors to accept collateral in partial or complete satisfaction of obligation, id. $\$ 1001.620$; elimination of special treatment relating to waiver around consumer goods transactions, $i d$. $\S 2.1001 .602$; abrogation of remedies for secured party's failure to comply with article, id. $\$ 2.1001 .624$; and abrogation of an action in which deficiency or surplus is in issue, id. $\$ 2.1001 .626$.

43. See Little River Band of Ottawa Indians, Ordinance No. 04-800-01 §5.02 (2004), https://www.lrboi-nsn.gov/images/docs/council/docs/ordinances/Tribal_Secured_Transactions_Ordinance_04-800-01.pdf [https://perma.cc/YXK8-LDSP]. The incorporation of Michigan's version of the UCC included a repeal of a prior secured transactions ordinance known as the Tribal Uniform Commercial Code. See id. ("The intent of this ordinance is to replace ordinance \# 01-800-01 (the 2001 'Tribal Uniform Commercial Code') .....").

44. See 12.201 Little Traverse Band of Odawa Tribe Code $\S 1.5$ (2003), https://www.ltbbodawa-nsn.gov/TribalCode.pdf [https://perma.cc/4CSJ-S46V]. The Little Traverse Band of Odawa Tribe incorporated Michigan's version of the UCC via ordinance to apply only to security interests granted by a tribal party. A tribal party is defined in the ordinance as "the Tribe and any division, subdivision, branch, department, board, committee, commission, agency, instrumentality, or entity wholly-owned or wholly-controlled, directly or indirectly, by the Tribe, along with the successors and assigns of each." Id.

45. See 9 Mashantucket Pequot Tribal Nation Code $\S 1$ (2008) (on file with Author). The law provides for the incorporation of the Connecticut UCC for the creation of secured transactions on tribal property.

46. See 18 Mille Lacs Band Stat. Ann. § 301 (2014), https://millelacsband.com/ content/3-government/13-legislative-branch/title-18-commercial-practices.pdf [https:// perma.cc/E4DQ-XS7Y]; William D. Hawkland et al., Uniform Commercial Code SerIEs, § 9-101:2 (2017).

47. See Mohegan Tribal Ordinance $\S 95-720-1$ (1995) (on file with Author). Article III, Section 301 of this Mohegan Tribal Ordinance adopts as substantive law: (i) law as set forth in any Mohegan Tribal ordinances or regulations, and (ii) the general statutes of the state of Connecticut and cases interpreting those statutes, except those that conflict with any written Mohegan Tribal law. Id.

48. See 4 Nottawaseppi Huron Band of the Potawatomi $\S 4.1-4$ (2008), https://ecode360.com/29876612 [https://perma.cc/Q2JJ-Y3MV].

49. See 7 Pascua Yaqui Tribal Code $\$ \$ 5-10,5-20$ (2010), https://www.pascuay aqui-nsn.gov/_static_pages/tribalcodes/docs/7_PYTC/5_Secured_Transactions.pdf [https://perma.cc/6FGK-DREE] (collectively known as the Secured Transactions Ordinance). The Ordinance adopted the Arizona UCC provisions with few modifications relating to sovereign immunity claims.

50. See Pokagon Band of Potawatomi Indians Secured Transactions CODE $§ 2 \mathrm{~A}$ (2005), http://www.pokagonband-nsn.gov/sites/default/files/assets/depart ment/government/form/2012/secured-transactions-code-836-633.pdf [https://perma.cc/ C5S8-TRH8] (incorporating Michigan's version of the UCC into tribal law).

51. See 13 Ponca Tribe of Neb. Tribal Code § 13-4-1 (2009), https:// www.poncatribe-ne.org/wp-content/uploads/2019/06/law_codetitle_v13_190501.pdf [https://perma.cc/9EDA-B42A] (incorporating Iowa's version of the UCC into tribal law). The limits of this ordinance relate to "the tribe, and all of its governmental authorities, instrumentalities, subdivisions, subsidiaries, and departments, including 
Lake Superior (Wisconsin), ${ }^{52}$ the San Manuel Band of Mission Indians (California, 2004), ${ }^{53}$ the Sault Ste. Marie Tribe of Chippewa Indians (Michigan, 2005), ${ }^{54}$ the Snoqualmie Tribe (Washington, 2008), ${ }^{55}$ the Spirit Lake Tribe (North Dakota, 1988), ${ }^{56}$ the Stockbridge-Munsee Tribe (New York, 2005), ${ }^{57}$ and the Tulalip Tribe (Washington, 2001). ${ }^{58}$

the successors and assigns of all the foregoing." Id. § 13-3-1; see also HAWKLAND ET AL., supra note 46, § 9-101:2.

52. 52 Red Cliff Band of Lake Superior Chippewa Tribal Code $§ 52.2 .4$, http://redcliff-nsn.gov/Government/TribalChapters/Chapter52.pdf [https://perma.cc/ 962Z-MPKP]. The Red Cliff Band of Lake Superior of Wisconsin incorporated the Wisconsin version of the UCC as Title 52 of its Tribal Chapter, identifying Articles 1, 8 , and 9 of the Wisconsin UCC as adopted by tribal law. The date of its adoption is unknown.

53. See 25 San Manuel Band of Mission Indians Tribal Code $§ 25.4$ (2004), https://www.sanmanuel-nsn.gov/portals/1/TribalGovernment/TribalLaws/San_Manuel _Secured_Transactions_Ordinance_Amended_July_12_2016.pdf [https://perma.cc/ BTB6-2UT7]. The ordinance was subsequently amended in 2009 and again in 2016. The law incorporates the California version of the UCC for purposes of security interests created by the tribe on tribal property or by tribal enterprises. Id. $\S 25.3$. The code incorporates the state filing system as the means of perfection.

54. See 99 Sault Ste. Marie Tribe of Chippewa Indians Tribal Code $\S 99.101$ (2005). The ordinance is limited to the creation of secured interests in gaming-related enterprise property. Id. $\S 99.104(1)$. The ordinance incorporated the Michigan UCC as in effect from time to time. Id. $\S 99.102(6)$.

55. See 14.3 Snoqualmie Tribal Code $\$ 3.0$ (2008), https://www.snoqualmie tribe.us/sites/default/files/secured_transactions_act.14.3.codified.pdf [https://perma.cc/ 6EDL-BJEF].

56. In 1988, the Spirit Lake Tribe adopted Resolution A05-89-030, which created the Spirit Lake Commercial Code. That Code included a chapter on secured transactions. 10 Devils Lake Sioux Law AND Order Code $§ 11$ (1988), http:// www.spiritlakenation.com/data/upfiles/media/Title_11_Commercial_Code.pdf [https:// perma.cc/QPM6-UVX8]. The secured transactions laws enacted by Spirit Lake incorporate the UCC as put forth by the American Law Institute ("ALI") and National Conference of Commissioners on Uniform State Laws ("NCCUSL"). The Code provides for filing as established by the North Dakota "Century Code Chapter 41-09." The Century Code is the official legislative reporter for North Dakota statutes. 41 North Dakota Century Code § 41-09 (1998), https://www.legis.nd.gov/cencode/ t41c09.pdf\#nameddest=41-09-01 [https://perma.cc/4YCH-MD7D].

57. See 57 Stockbridge-Munsee Tribal Law $\$ 59.1$ (2005), https://www.mohican.com/mt-content/uploads/2015/11/ch-59-ucc_final_6-29-09_563a76ca77ea4.pdf [https://perma.cc/YJ9T-FF2T]. The Stockbridge-Munsee Community adopted a secured transactions law that incorporated New York's UCC. The law applied to any security interest created under the jurisdiction of the Stockbridge-Munsee Tribe including any created in tribal property. Id.

58. See 10 Tulalip Tribal Code $\S 10.20 .030$ (2001), https://www.codepublishing. com/WA/Tulalip/\#!/html/Tulalip10/Tulalip1020.html [https://perma.cc/3UVJ-2X6U]. The Tulalip Tribe incorporated the state of Washington's Commercial Code into its tribal code. Adoption was uniform with the exception of place for filing. Id. $\S 10.20 .030$. 


\section{B. Tribes That Have Adopted the ULC Version of the UCC into Tribal Law}

Some tribes have elected to adopt the UCC as developed by the ULC, rather than any state-specific modifications to the UCC version. This approach has the advantages of hewing closely to the original UCC without the burden of non-uniform state amendments, if any. Particularly, since most of the tribes that have adopted the ULC version have added their own non-uniform amendments, it allows the tribes to avoid conflict when their own tribal amendments may be in conflict with state amendments.

To date, eight tribes have adopted or modified the UCC into tribal law; those tribes include: the Cherokee OTSA (Oklahoma, 2001), ${ }^{59}$ the Eastern Cherokee Reservation (North Carolina, 2001), ${ }^{60}$ the Forest County Potawatomi Community (Wisconsin, 2015) ${ }^{61}$ the Poarch Band of Creeks (Alabama, 2004), ${ }^{62}$ the Rincon Band of Luiseño Indians (California, 2008), ${ }^{63}$ the Sac and Fox Tribe of the Mississippi in Iowa (2007), ${ }^{64}$ the Seminole Tribe of Florida (2001), ${ }^{65}$ the Turtle

59. See 80 CHeroke CODE $\$ 9$ (2001), https://attorneygeneral.cherokee.org/me dia/5upcrg3j/word-searchable-full-code.pdf [https://perma.cc/7CWP-8UZU]. In 2001, the Cherokee Nation of Oklahoma adopted Title 80 of its tribal code, based on the UCC by the ALI and NCCUSL. The code includes a secured transactions section at Article 9.

60. See 2 Eastern Band of Cherokee Indians Tribal Code $\S 16 \mathrm{D}-1$ (a) (2001), https://library.municode.com/tribes_and_tribal_nations/eastern_band_ of cherokee indians/codes/code_of_ordinances?nodeId=PTIICOOR CH16DUCOR TRCAGAEN_S16D-1ADAR19 [https://perma.cc/924K-YNRT]. In 2001, the Eastern Band of Cherokees adopted Articles 1 and 9 for the limited purpose of enabling the tribe and any tribal related enterprise (particularly casino operations) to create secured transactions. The ordinance was amended in 2003. It specifically incorporates the most recent version of the UCC as published by the ALI and NCCUSL.

61. In 2015, the Forest County Potawatomi Tribe adopted the Model Tribal Secured Transactions Act as Chapter 5-5, known as the Forest County Potawatomi Uniform Commercial Code: Secured Transactions Ordinance. See generally 5-5 ForEsT County Potawatomi Uniform Commercial Code: Secured Transactions OrDINANCE (2005), https://www.fcpotawatomi.com/wp-content/uploads/2015/06/Chapter -5-5-UCC-05.09.2015.pdf [https://perma.cc/NHT2-2KRS].

62. 43 Poarch Creek Indian Law \& Order Code § 43-1-1 (2020), https://li brary.municode.com/tribes_and_tribal_nations/poarch_band_of_creek_indians/codes/ code_of_ordinances?nodeId=TIT43SETR_CHISETR_S43-1-1PU [https://perma.cc/ E64K-6Z37].

63. In 2008, the Rincon Band of Luiseño Indians incorporated the UCC (Articles 1-9) into tribal law. The tribe later amended the law, making various amendments to address specific tribal concerns. See Resolution No. 2008-03. The tribal law is known as Rincon Tribal UCC and goes under the general numbering convention designated by the UCC. 6 Rincon Tribal CODE $\S 6.500$ (2008), https://rincon-nsn.gov/wp-con tent/uploads/2019/05/6_0500-Tribal-Uniform-Commercial-Code.pdf [https://perma.cc/ JU6N-SGTY].

64. See Sac \& Fox Nation Code of Laws $\S 4-2101$ (2007) (on file with Author) (incorporating the UCC as adopted by the ULC).

65. The Seminole Tribe of Florida's variation of the UCC describes itself as:

[T] he Seminole Tribe of Florida adopted a variation of UCC Revised Article

9 (together with relevant portions of UCC Articles 1 and 8) as its Secured 


\author{
Mountain Reservation (North Dakota, 2012) ${ }^{66}$ and the Warm Springs \\ Reservation (Oregon) ${ }^{67}$
}

\title{
C. Tribes That Have Adopted Provisions of the UCC Relating to Sales of Accounts and Chattel Paper
}

Some tribes, in lieu of adopting the entirety of the UCC, have adopted provisions relating to the limited circumstance of selling accounts or chattel paper. These provisions are aimed at encouraging financial firms to do business on tribal lands by facilitating the negotiability of instruments and paper that would limit those firms' risk. To date, there are currently six tribes with these adoptions: the Chitimacha Tribe of Louisiana (2004), ${ }^{68}$ the Fort Peck Indian Reservation

\footnotetext{
Transaction Ordinance, Ordinance No. C-01-01 (August 27, 2001). Under the Seminole ordinance, the designated central filing office is the same as under the Florida UCC, the privatized Florida Secured Transaction Registry. Although Florida is a P.L. 280 jurisdiction and portions of the Florida UCC might therefore apply on the Seminole Tribe's reservation, the Seminole Tribe's Secured Transaction Ordinance was necessary to enable the tribe to grant security interests in tribal assets, since the scope of revised Article 9 of the Florida UCC still excludes any transfers by a government or a governmental unit.
}

Burt Bruton, Financing Issues in Indian Country, Greenberg Traurig 1, 7-20 (2005), https://www.google.com/url? sa $=$ t\&rct=j\&q=\&esrc $=$ s\&source=web\& $\mathrm{cd}=1 \&$ ved=2ahUKEwjMovDfh8fmAhUSrlkKHT9yDZYQFjAAegQIARAC\&url= https $\% 3 \mathrm{~A} \% 2 \mathrm{~F} \% 2 \mathrm{Fcdn}$.ymaws.com $\% 2$ Facrel.site-ym.com $\% 2$ Fresource $\% 2$ Fcollec tion \%2FA8CB323B-4770-4216-89C4-697A65FD236D\%2FBruton-F05-Indian_Coun try_Finance.doc\&usg=AOvVaw22icYJ5hIsu-D6BZxhbVb [https://perma.cc/ZDB2$\mathrm{T} 2 \mathrm{CG}]$.

66. In 2012, the Turtle Mountain Reservation adopted a Uniform Commercial Code based in part on the UCC. See generally 24 Turtle Mountain Band of ChipPEwa Indians Commercial Code (2012), https://www.tm.edu/wp-content/uploads/ files/Academics/Paralegal\%20Resources/TITLE\%2024-Commercial.pdf [https:// perma.cc/YY8V-Y5NR].

67. The Warm Springs Tribe adopted a version of the UCC. In the introductory Article, the Act describes itself as:

To the extent practical, this chapter follows Article 9 of the Uniform Commercial Code (UCC Article 9) published by the National Conference of Commissioners on Uniform State Laws. However, this chapter has been modified in some respects to suit the unique needs and situation on the Warm Springs Reservation and to promote ease of understanding. In particular, the Tribal Council has determined that these types of matters are best handled in an administrative forum that facilitates practical arrangements between debtors and creditors and provides an expedited process that quickly and fairly resolves disputes. In addition, it deals with matters beyond the scope of UCC Article 9 such as possessory liens and leases of personal property.

731 Warm Springs Tribal Code $§ 4-2101$, https://warmsprings-nsn.gov/bchapter/ personal-property-secured-transactions-statutory-liens/ [https://perma.cc/AJ5MZ8WZ].

68. In 1989, the Chitimacha adopted a commercial code based in part on provisions of the UCC. In 2004, the tribe amended the code to include a provision on secured transactions, modeled on the UCC. See 18 Chitimacha Comprenensive CODES OF JUSTICE $§ 101$ (2004), http://www.chitimacha.gov/sites/default/files/CCCJ \%20Title\%20XVIII\%20-\%20Tribal\%20Bond\%20Legislation.pdf [https:/perma.cc/ 
(Montana, 1992), ${ }^{69}$ the Hoopa Valley Reservation (California, 1998), ${ }^{70}$ the Mississippi Choctaw Reservation (2011), ${ }^{71}$ the Northern Cheyenne Indian Reservation (Montana, 1998), ${ }^{72}$ and the Sisseton Wahpeton Oyate of the Lake Traverse Reservation (South Dakota, 1996). ${ }^{73}$

\section{Tribes That Have Adopted the MTSTA or the R-MTSTA into Tribal Law}

In 2002, the ULC convened with the participation of tribal representatives to create a uniform code that would facilitate economic development. ${ }^{74}$ The project's purpose was to "cultivate an environment

GG6B-JRRF]. The ordinance describes itself as limited to sales of accounts and chattel paper in its title, but the provisions of the law more closely resemble the more comprehensive approach of the UCC toward personal property. See id. $\S 101(\mathrm{~F})$.

69. See 24 Fort Peck Tribes Comprehensive Code of Justice $\$ 802$ (1992) (on file with Author). In 1992, the Assiniboine and Sioux Tribes of the Fort Peck Reservation in Wyoming adopted Sections 9-901, 9-202, and 9-903. Section 9-901 incorporates the most recent version of the UCC as adopted by the ALI and NCCUSL relating to the sales of accounts and chattel paper. It further provides for self-help remedies that do not otherwise conflict with tribal laws relating to self-help repossession. Chapter 8 of the tribal code restricts self-help repossession to cases where the owner of the property to be repossessed has given written permission for the creditor to repossess.

70. On June 8, 1998, Ordinance Number 10-98, known as the "Ordinance of the Hoopa Valley Tribe Regarding Approval of the Tribal Commercial Transactions Code," Title 57 of the Hoopa Tribal Code, was approved. That Code includes a secured transactions code dealing with sales of accounts and chattel paper. See 57 Hoopa TRIBAL CODE $\$ 2.101$ (1998), https://www.hoopa-nsn.gov/wp-content/ uploads/2015/06/Title57-CommercialTransactions062098.pdf [https://perma.cc/5C579N82]. The ordinance adopted by the Hoopa Valley Tribe was based on a model secured transactions law created by the University of Montana's Tribal Indian Law Clinic. See Bruce A. King, The Model Tribal Secured Transactions Act, Indian L. NewsL. 1, 4 (Jan. 2007), https://narf.org/nill/bulletins/lawreviews/articles/indianlawnewsletter.pdf [https://perma.cc/233R-MUUH].

71. See 26 Mississippi Choctaw Tribal Code § 26-1-1-2(6) (2011), http:// www.choctaw.org/government/tribal_code/Title \%2026-\%20Uniform\%20Commercial \%20Code.pdf [https://perma.cc/CPM3-G7NX].

72. On October 23, 1998, the Northern Cheyenne Tribal Council adopted Resolution No. DOI-013(99), known as the Northern Cheyenne Uniform Commercial Code. See Northern Cheyenne Uniform Commercial Code (1999), https://narf.org/nill/ codes/northern_cheyenne/ucc.PDF [https://perma.cc/T35C-FL8S]. The Code applies to sales of accounts and chattel paper. Id. § 9-101.

73. In 1996, under tribal council resolution No. SWST 96-078, the Sisseton Wahpeton Oyate Tribe of the Lake Traverse in South Dakota adopted portions of the UCC for creations of security interests in chattel paper and accounts. See SissETON-WAHPETON SiOuX TRIBAL CODE \$ 69-18-01 (1996), https://narf.org/nill/codes/sisseton_wahpeton/Chapter69.pdf [https://perma.cc/9WMC-3N98].

74. William Henning \& Fred Miller, State of the UCC: A Look Back at 2007, 64 UCC BuLL. 1, 3 (2008) (noting that the emergence of the MTSTA arose because of identified needs to facilitate economic activity on tribes by facilitating access to credit); Tim Berg, Growing Indian Economies, ARIz. ATT'y 30, 32 (2006), https:// www.myazbar.org/azattorney/pdf_articles/0306tribal.pdf [https://perma.cc/FWH2D9AT] ("Access to financing and capital is key to economic growth, and such access is hampered in Indian Country by the lack of standard laws governing business and lending transactions."). 
conducive to entrepreneurship, lending, and investment," in tribal territories. $^{75}$ In 2001, the Federal Reserve Board in Minneapolis conducted a study that found "as [t]ribal economies expand and capital needs increase, $[\mathrm{t}$ ]ribal governments need to cultivate an environment conducive to entrepreneurship, lending and investment. A key component of that type of environment is a legal infrastructure that supports contract enforcement and facilitates commercial activity." ${ }^{\prime \prime 6}$ Subsequently, the ULC put forth a revision of the MTSTA. The project was supported by a cross section of tribes from across the country, though not all the tribes that participated in the project have adopted the uniform law designed for tribes. ${ }^{77}$

Thirteen tribes have adopted the MTSTA: the Northern Arapaho Tribe of the Wind River Reservation (Wyoming, 2014), ${ }^{78}$ the Chippewa Cree Tribe (Montana, 2012), ${ }^{79}$ the Colville Reservation (Washington, 2011), ${ }^{80}$ the Fond du Lac Reservation (Minnesota, 2010), ${ }^{81}$

75. See also Hawkland ET AL., supra note 46, § 9-101:2. The 2005 Implementation Guide identifies the purposes of the Model Act as: "(1) to assist tribal legislatures in their review, adaptation and enactment of the Act; (2) to facilitate the use and understanding of the Act by tribal judges, legal counsel and individuals promoting business development in Indian Country; and (3) to assist nontribal lenders and businesses in understanding the similarities and differences between the Act and corresponding provisions of the Uniform Commercial Code ('UCC')." Id.

76. Id. The commission worked with appointed members of numerous tribes with the support of the Federal Reserve Bank of Minneapolis to create a model secured transactions law adapted from Article 9 of the UCC. The committee grappled with issues of adapting Article 9 of the UCC to be a suitable use for tribes. Concerns of the committee included: "simplifying the act; appropriately reflecting tribal law, customs, and traditions; integrating the act into whatever body of commercial law might exist within a particular tribe; protecting the sovereign immunity of a tribe; and preserving the core concepts of Article 9 so that tribal and state law can be harmonized to the extent practicable." Id.

77. Notably, the Nez Perce Tribe and the Umatilla Tribe have yet to adopt any secured transactions law. See William H. Henning, A History and Description of the Model Tribal Secured Transactions Act Project, InT'L Ass'N Com. Adm'rs 1, 3 https:// www.iaca.org/wp-content/uploads/MTSTA_Article.pdf [https://perma.cc/NR9Q95M3].

78. In 2013, the Arapaho Tribe of the Wind River Reservation adopted a modified version of the MTSTA and UCC Article 9, effective December 1, 2014. See 18 Northern Arapaho Tribal Code § 9-701 (2014), http://northernarapaho.com/wp/ bfd_download/title-18-ucc/ [https://perma.cc/UX2B-YGPU]. The Arapaho version of the UCC adopts the substance of the MTSTA with the numbering system of the UCC, reserving inapplicable UCC sections for future use. See id.

79. The adoption of the MTSTA includes the Chippewa Cree Band at Rocky Boy's Reservation and Off-Reservation Trust Land, Montana. See Chippewa CreE Tribe Secured Transactions Code (2012), https://sosmt.gov/Portals/142/Business/ Forms/UCCTribalNations/UCC_Article_9_Secured-Chippewa_Cree_2012_(Final).pdf [https://perma.cc/HL7D-LLW4]. See also HawkLAND ET AL., supra note 46, § 9-101:2.

80. See 12 Colville Tribal Code $\S 12-9$ (2011), https://www.cct-cbc.com/s/129.pdf [https://perma.cc/GG3J-PRKR].

81. In 2010, the Fond du Lac Band of Lake Superior Chippewa adopted Ordinance No. 07/10, incorporating the MTSTA provisions for the tribe. See generally Fond du Lac Band of Lake Superior Chippewa Secured Transactions Ordi- 
Leech Lake Reservation (Minnesota, 2010) ${ }^{82}$ the Oglala Sioux Tribe (South Dakota, 2008), ${ }^{83}$ the Rosebud Sioux (South Dakota), ${ }^{84}$ the Sac and Fox Tribe of Oklahoma (2007), ${ }^{85}$ the Seminole Nation of Oklahoma (2007), ${ }^{86}$ and the Standing Rock Sioux Tribe (the Dakotas, 2009). ${ }^{87}$ At the time of this Article's publication, no tribes have adopted the R-MTSTA.

\section{E. Tribes That Have Adopted a Non-Uniform Secured Transactions Law}

Several tribes have adopted laws that either create non-uniform ways of establishing secured transactions in their tribal territories, or that attempt to reconcile the existence of security interests created outside of tribal law. These non-uniform adoptions vary widely in both the scope and matter addressed:

- The Crow Creek Sioux Tribe adopted a non-uniform law relating to the creation of pledges and other security provisions on tribal lands. ${ }^{88}$

- The Eastern Shoshone appear to recognize the existence of creditors' remedies and security interests but do not define them or set them out in particular. Chapter 14-15-1 limits the ability of creditors to use self-help and acceleration remedies and pro-

NANCE (2010), http://www.fdlrez.com/government/ords/07-10SecuredTransactionsOrdinance_2016.03.10.pdf [https://perma.cc/7AAQ-ARES].

82. Hawkland ET AL., supra note 46, § 9-101:2.

83. On July 30, 2007, the Oglala Sioux Pine Ridge Reservation adopted the MTSTA. See Sue Woodrow \& Dani Daugherty, Oglala Sioux and State of South Dakota Sign Historic Lien-Filing Agreement, Fed. Res. Bank Minneapolis (Nov. 1, 2008), https://www.minneapolisfed.org/article/2008/oglala-sioux-and-state-of-south-dakotasign-historic-lienfiling-agreement [https://perma.cc/NN9Q-25SC].

84. See generally 14 Rosebud Sioux Tribal Code, https://www.narf.org/nill/ codes/rosebudcode/title14commcode.pdf [https://perma.cc/NL8L-S7AL]; see also South Dakota Tribal Court Handbook (2006), https://ujs.sd.gov/uploads/docs/Indian Law\%20Handbook.pdf [https://perma.cc/G4ZZ-CRRH]; HawKLAND ET AL., supra note 46, § 9-101:2.

85. The Sac and Fox UCC became effective on September 1, 2007. See 27 SAC \& Fox NATION CODE OF LAws § 9-701 (2007), http://sacandfoxnation-nsn.gov/sites/sfnation/uploads/documents/SF_CODES_Law/code_of_laws/27_UCC_-_Article_9_-_Secured_Transactions.pdf [https://perma.cc/Z7TQ-RBXZ]; see also HAWKLAND ET AL., supra note 46, § 9-101:2.

86. See 29 Seminole Nation of OKlahoma Code (2007), https://narf.org/nill/ codes/seminole_nation_ok/index.html [https://perma.cc/7PW5-F9KX].

87. The Standing Rock Sioux Tribe adopted its first commercial code in 1999. See South Dakota Tribal Court Handbook, S.D. Unified Jud. Sys. 1, 44 (2006), https:// ujs.sd.gov/uploads/docs/IndianLaw\%20Handbook.pdf [https://perma.cc/G4ZZCRRH]. In 2009, the tribe adopted a revised, but temporary, commercial code under Resolution 538-09. That Code was abrogated in favor of the current commercial code adopted June 4, 2014. See 24 Standing Rock Sioux Tribal Code of Justice $§ 1$ (2014), https://www.standingrock.org/sites/default/files/uploads/title_xxiv_-_standing_rock_commercial_code.pdf [https://perma.cc/L445-2JRU].

88. See Crow Creek Sioux CoDE \$ 8-2 (1997), https://narf.org/nill/codes/ crow_creek_sioux/index.html [https://perma.cc/Q3J4-FJX3]. 
vides for an action to foreclose on interests in personal property. ${ }^{89}$

- The Fort McDermitt Paiute and Shoshone Tribe has a non-uniform limitation recognizing the enforceability of security interests, while limiting the mechanisms creditors can undertake to foreclose on personal property. ${ }^{90}$

- The Fort McDowell Yavapai Nation adopted an ordinance that allowed the tribe to create a security interest in (or pledge) to "secure directly or indirectly the payment of principal or redemption price of, or interest on, any bonds . . .."91

- The Yankton Sioux Tribe of South Dakota's code provides for certain creditors' rights and responsibilities. Particularly, the code provides for the enforcement of a security interest through tribal courts. ${ }^{92}$

- Finally, the Kalispel Indian Community has repealed a secured transactions law but has not replaced it with another. ${ }^{93}$

\section{F. Tribal Approaches to Filing Systems}

The tribes that have adopted secured transactions laws have also lacked uniformity about where to file those interests. The tribal laws reveal three approaches tribes have taken for addressing where filing should occur: (1) entering into compacts with local state filing offices; (2) incorporating a local state filing system without entering into a compact with the state; and (3) maintaining a filing system on tribal lands. Five tribes in three states have entered into compacts for the local state filing office to handle tribal filing:

- Montana entered into compacts with the Crow Nation in $2008^{94}$ and with the Chippewa Cree tribe in 2017.95

89. See 14 Eastern Shoshone Code $\S \S 14-15-1,14-15-2$ (2004), https:// www.windrivertribalcourt.com//wp-content/uploads/2018/05/Title_XIV.pdf [https:// perma.cc/7F65-XPNL]. See also HawklAND ET AL., supra note 46, § 9-101:2.

90. See 20 Fort McDermitt Paiute and Shoshone Tribe Code $\S 1$ (2015), https://www.narf.org/nill/codes/fort_mcdermitt/ch20.pdf [https://perma.cc/4UMYFTAR].

91. See The Fort McDowell Yavapai Nation Law \& Order Code $§ 2-100$ (2015), https://www.fmyn.org/wp-content/uploads/Fort-McDowell-Word-Proofs-3-272015.pdf [https://perma.cc/EPQ5-VE8M]. The law does not provide a mechanism or a designation for filing of competing interests. $I d$.

92. 9 Yankton Sioux Tribal Code $\$ 9-1-2$ (1995), https://narf.org/nill/codes/ yanktoncode/yanktoncodet9creditors.html [https://perma.cc/MCM9-S7KA].

93. The tribe's former secured transactions law was in the tribe's Commercial Code. 28.28 Kalispel Code (West, through Mar. 28, 2012). It has been repealed.

94. See Crow Nation, State of Montana Sign UCC Filing Compact, FED. Res. BANK Minneapolis (May 1, 2008), https://www.minneapolisfed.org/article/2008/ crow-nation-state-of-montana-sign-ucc-filing-compact [https://perma.cc/P3MJ$7 \mathrm{MBY}$. The Crow Nation was the first tribe in the country to enter into a filing compact with a state government. $I d$.

95. See generally Compact Between Chippewa Cree Tribe of Rocky Boy's Reservation and Office of the Montana Secretary of State for a Joint Sovereign Filing System, 
- South Dakota entered into compacts with the Cheyenne River Reservation in $2000^{96}$ and the Oglala Sioux Tribe in 2008. ${ }^{97}$

- Minnesota entered into a compact with the Leech Lake Reservation for filings with the secretary of state. ${ }^{98}$

So far, the compacts have had limited effect. For example, to date only one tribe in Montana has had filings filed under the state compactthe Crow Tribe. Since 2008, the Montana Secretary of State has received only eighty-seven filings under the state compact. That number shrinks again when we consider the number of filings made as duplicates, amendments, or termination statements. Thirty-two of the filings were duplicated across the UCC filing system and the agricultural lien filing system, reducing the total number of original filings to fiftyfive. Those filings all originated from seven creditors since $2008 .{ }^{99}$

The most common approach to filing systems by tribes is to incorporate a local state filing system without entering into a compact with the state. The effect of these provisions is difficult to measure. Unlike the tribes that have entered into compacts with their states, where no compact exists, states do not track whether a financing statement has been entered into under state law or tribal law. ${ }^{100}$ Tribes that identify state filing offices as the place for filing financing statements but that lack a compact with the state include the following:

Mo. Secretary ST. (Apr. 4, 2017), https://sosmt.gov/Portals/142/Business/Forms/ UCCTribalNations/ChippewaCreeCompact.pdf [https://perma.cc/N5NY-EYSH].

96. See generally Joint Powers Agreement Between South Dakota Secretary of State and Cheyenne River Sioux Tribe, S.D. SeCretary ST. (July 2000), https://sdsos.gov/ docs/ucc-docs/Cheyenne\%20River\%20Sioux\%20Tribe\%20Joint\%20Powers\%20

Agreement.pdf [https://perma.cc/4N7S-7R99].

97. Woodrow \& Daugherty, supra note 83.

98. See generally Leech Lake Band and State of Minnesota Sign Lien-Filing Agreement, Fed. Res. Bank Minneapolis (Jan. 1, 2012), https://www.minneapolisfed.org/ article/2012/leech-lake-band-and-state-of-minnesota-sign-lienfiling-agreement [https:/ /perma.cc/FH63-KVEJ].

99. See Report from Montana Secretary of State (November 2019) (on file with Author).

100. This inability to track data relating to tribal transactions has become an increasing source of frustration amongst researchers seeking to understand tribal commercial practices more completely. There are good reasons why tribes may be reluctant to participate with researchers attempting to understand tribal practices more completely. For example, Bryan McKinley Brayboy and Donna Deyhle note that "sometimes researchers are 'blocked' by participants who decide they are unworthy or not to be trusted with local 'insider' information." Bryan McKinley Brayboy \& Donna Deyhle, Insider-Outsider: Researchers in American Indian Communities, in 39 Theory into Practice 163, 163 (2000). As they go on to say, gathering Native American stories, of which commercial practices and legal structural processes are an integral part, see, e.g., Jessica Shoemaker, The Challenges of American Indian Land Tenure and the Vastness of Entrepreneurial Potential, in Creating Private Sector Economies in Native America: Sustainable Development Through EntrePRENEURSHIP 67 (Robert J. Miller et al. eds., 2019), is "particularly political because of the history of research in the lives of indigenous people." Brayboy \& Deyhle, supra note 100 , at 163 . Still, this means that researchers must do a better job building trust within tribes to build thicker descriptions. 
- Alabama: the Poarch Band of Creeks ${ }^{101}$

- Arizona: the Pascua Yaqui Reservation ${ }^{102}$

- California: the Rincon Band of Luiseño Indians, ${ }^{103}$ the San Manuel Band of Mission Indians ${ }^{104}$

- Connecticut: the Mashantucket Pequot Tribe, ${ }^{105}$ the Mohegan Tribe ${ }^{106}$

- Iowa: the Ponca Tribe ${ }^{107}$

- Michigan: the Grand Traverse Band of Ottawa and Chippewa Indians, ${ }^{108}$ the Little River Band of Ottawa Indians, ${ }^{109}$ the Nottawaseppi Huron Band of the Potawatomi, ${ }^{110}$ the Pokagon Band of Potawatomi ${ }^{111}$

101. 43 Poarch Creek Indian Law \& Order Code $§ 43-1-1$ (2020), https://library.municode.com/tribes_and_tribal_nations/poarch_band_of_creek_indians/codes/ code_of_ordinances?nodeId=TIT43SETR_CHISETR_S43-1-1PU [https://perma.cc/ E64K-6̄ 37$]$.

102. See 7 Pascua Yaqui Tribal Code $\S \S 5-10, \quad 5-20$ (2010), https:// www.pascuayaqui-nsn.gov/_static_pages/tribalcodes/docs/7_PYTC/5_Secured_Transactions.pdf [https://perma.cc/6FGK-DREE].

103. See 6 RinCON TRIBAL CODE $\$ 6.500$ (2008), https://rincon-nsn.gov/wp-content/ uploads/2019/05/6_0500-Tribal-Uniform-Commercial-Code.pdf [https://perma.cc/ JU6N-SGTY].

104. See 25 San Manuel Band of Mission Indians Tribal Code $§ 25.4$ (2004), https://www.sanmanuel-nsn.gov/portals/1/TribalGovernment/TribalLaws/

San_Manuel_Secured_Transactions_Ordinance_Amended_July_12_2016.pdf [https:// perma.cc/BTB6-2UT7].

105. See 9 Mashantucket Pequot Tribal Nation Code $\S 1$ (2008) (on file with Author).

106. See Mohegan Tribal Ordinance 95-720-1 (1995) (on file with Author).

107. See 13 Ponca Tribe of Neb. Tribal Code $\S 13-4-1$ (2009), https:// www.poncatribe-ne.org/wp-content/uploads/2019/06/law_codetitle_v13_190501.pdf [https://perma.cc/9EDA-B42A].

108. See 15 Grand Traverse Band of Ottawa and Chippewa Indians Tribal CODE $§ 104($ a) (2012), https://narf.org/nill/codes/grand_traverse/Title_15.pdf [https:// perma.cc/YA4C-4URK].

109. Tribal law identifies both the Secretary of State's office in Michigan and the Tribal Court as necessary places to file a financing statement for pledges of revenues that belong to the tribe. See Little River Secured Transactions Ordinance $\S 4.04$, https://www.lrboi-nsn.gov/images/docs/council/docs/ordinances/Tribal_Secured _Transactions_Ordinance_04-800-01.pdf [https://perma.cc/G5MH-88TU]. It states,

Notwithstanding any other provision of the contract UCC, the Michigan UCC, or this Ordinance to the contrary a security interest granted in Pledged Revenues in which the applicable Tribal Party has rights shall be created and attach upon the giving of value and the granting of such a security interest by such Tribal Party in a writing executed by that Tribal Party, and such security interest may be perfected only by the filing of an initial financing statement with respect to such security interest with the Tribal Court and in the Office of the Secretary of State for the state of Michigan as Id. if all of such Pledged Revenues were accounts.

110. See 4 Nottawaseppi Huron Band of the Potawatomi $\S 4.1-4$ (2008), https://ecode360.com/29876612 [https://perma.cc/Q2JJ-Y3MV].

111. See generally Pokagon Band of Potawatomi Indians Secured TransacTIONS CODE (2005), http://www.pokagonband-nsn.gov/sites/default/files/assets/depart- 
- Minnesota: the Mille Lacs Band of Chippewa, ${ }^{112}$ the Sault Ste. Marie Tribe of Chippewa Indians ${ }^{113}$

- Montana: the Fort Peck Indian Reservation ${ }^{114}$

- Nevada: the Stockbridge-Munsee Tribe ${ }^{115}$

- North Carolina: the Eastern Cherokee Reservation ${ }^{116}$

- North Dakota: the Fort Berthold Reservation, the Spirit Lake Tribe ${ }^{117}$

- Oregon: the Warm Springs Reservation ${ }^{118}$

- South Dakota: the Northern Cheyenne Reservation, ${ }^{119}$ the Rosebud Sioux Tribe,${ }^{120}$ the Standing Rock Sioux Tribe ${ }^{121}$

- Texas: the Kickapoo Traditional Tribe ${ }^{122}$

- Washington: the Colville Reservation, ${ }^{123}$ the Lummi Reservation $^{124}$

ment/government/form/2012/secured-transactions-code-836-633.pdf [https://perma.cc/ C5S8-TRH8].

112. See 18 Mille Lacs Band Stat. Ann. § 301 (2014), https://millelacsband.com/ content/3-government/13-legislative-branch/title-18-commercial-practices.pdf [https:// perma.cc/E4DQ-XS7Y].

113. See 99 Sault Ste. Marie Tribe of Chippewa Indians Tribal Code $\S 99.101$ (2005).

114. See 24 Fort Peck Tribes Comprehensive Code of Justice $§ 802$ (1992) (on file with Author).

115. See 57 Stockbridge-Munsee Tribal Law §59.1(b) (2005), https:// www.mohican.com/mt-content/uploads/2015/11/ch-59-ucc_final_6-29-

09_563a76ca77ea4.pdf [https://perma.cc/YJ9T-FF2T].

116. See 2 Eastern Band of Cherokee Indians Tribal Code $\S 16 D-1(a)$ (2001), https://library.municode.com/tribes_and_tribal_nations/eastern_band_of_ cherokee_indians/codes/code_of_ordinances?nodeId=PTIICOOR_CH16DUCORTR CAGAEN_S16D-1ADAR19[https://perma.cc/924K-YNRT].

117. 10 Devils Lake Sioux Law and Order Code $§ 11$ (1988), http:// www.spiritlakenation.com/data/upfiles/media/Title_11_Commercial_Code.pdf [https:// perma.cc/QPM6-UVX8].

118. 731 WARM SPRINGs TRIBAL CODE § 4-2101, https://warmsprings-nsn.gov/ bchapter/personal-property-secured-transactions-statutory-liens/ [https://perma.cc/ AJ5M-Z8WZ].

119. See Northern Cheyenne Uniform Commercial Code (1999), https:// narf.org/nill/codes/northern_cheyenne/ucc.PDF [https://perma.cc/T35C-FL8S].

120. See generally 14 Rosebud Sioux Tribal Code, https://www.narf.org/nill/ codes/rosebudcode/title14commcode.pdf [https://perma.cc/NL8L-S7AL].

121. See 24 Standing Rock Sioux Tribal Code of Justice § 24-501(a) (2014), https://www.standingrock.org/sites/default/files/uploads/title_xxiv_-_standing_rock_ commercial_code.pdf [https://perma.cc/6Y6N-FGMS].

122. See 25 Kickapoo Traditional Tribe of Texas Code $\S 1$ (2012) (on file with Author).

123. See 12 Colville Tribal Code, $\S 12-9-120$ (2011), https://www.cct-cbc.com/s/ 12-9.pdf [https://perma.cc/GG3J-PRKR].

124. 26 Lummi Nation Code OF LAws $§ 26.03 .010$ (a) (2016), https://narf.org/nill/ codes/lummi/26Commercial.pdf [https://perma.cc/9H54-LU95]. 
- Wisconsin: the Forest County Potawatomi Tribe, ${ }^{125}$ the Red Cliff Band of Lake Superior, ${ }^{126}$ the Snoqualmie Tribe ${ }^{127}$

- Wyoming: the Arapaho Tribe of the Wind River Reservation ${ }^{128}$ States that accept tribal filings without compacts do not maintain data regarding the number of creditors. In effect, these filings are commingled into the state's other filings.

Currently, twenty-two tribes maintain their own filing system on tribal lands. These are divided between filings made in tribal courts, filings made with other tribal administrative offices, and filings made in security-interest-specific filing offices.

- Eight tribes currently require filings in the tribal court, either with the tribal clerk of court or other office within the court system: the Bay Mills Indian Community ${ }^{129}$ the Blackfeet Reservation, ${ }^{130}$ the Chitimacha Tribe of Louisiana, ${ }^{131}$ the Fond du Lac Reservation, ${ }^{132}$ the Little River Band of Ottawa Indians, ${ }^{133}$ the Mississippi Choctaw Reservation, ${ }^{134}$ and the Sac and Fox Nation of Oklahoma. ${ }^{135}$

- Nine tribes require filing in other tribal administrative offices. For example, the Chevak tribe requires filings with the office of

125. See Forest County Potawatomi Uniform Commercial Code: Secured Transactions Ordinance $§ 5.1(A)$ (2005), https://www.fcpotawatomi.com/wp-content/uploads/2015/06/Chapter-5-5-UCC-05.09.2015.pdf [https://perma.cc/NHT22KRS].

126. See 52 Red Cliff Band of Lake Superior Chippewa Tribal Code $\S 52.2 .4$, http://redcliff-nsn.gov/Government/TribalChapters/Chapter52.pdf [https:// perma.cc/962Z-MPKP].

127. See 14.3 Snoqualmie Tribal Code $\$ 3.0$ (2008), https://www.snoqualmie tribe.us/sites/default/files/secured_transactions_act.14.3.codified.pdf [https://perma.cc/ 6EDL-BJEF].

128. See 18 Northern Arapaho Tribal Code $\S 9-701$ (2014), http://northern arapaho.com/wp/bfd_download/title-18-ucc/ [https://perma.cc/UX2B-YGPU].

129. See Secured Transactions Ordinance of Bay Mills Indian CommuNITY $\$ 1$ (1994), http://www.baymills.org/resources/Secured\%20transactions\%20or dinance.pdf [https://perma.cc/37MV-BEJR].

130. 1 BlacKFeET COMMERCIAL CODE (1990), https://www.narf.org/nill/codes/ blackfeetcode/ord81.pdf [https://perma.cc/9TN6-PQZ3].

131. See 18 Chitimacha Comprehensive Codes of Justice $§ 101$ (2004), http:// www.chitimacha.gov/sites/default/files/CCCJ\%20Title\%20XVIII\%20-\%20Tribal\%20 Bond\%20Legislation.pdf [https://perma.cc/GG6B-JRRF].

132. See generally Fond du Lac Band of Lake Superior Chippewa Secured Transactions Ordinance (2010), http://www.fdlrez.com/government/ords/07-10SecuredTransactionsOrdinance_2016.03.10.pdf [https://perma.cc/7AAQ-ARES].

133. See Little River Band of Ottawa Indians, Ordinance No. 04-800-01 §5.02 (2004), https://www.lrboi-nsn.gov/images/docs/council/docs/ordinances/Tribal_Secured_Transactions_Ordinance_04-800-01.pdf [https://perma.cc/YXK8-LDSP].

134. See 26 Mississippi Choctaw Tribal Code $\$ 26-1-1-2(6)$ (2011), http:// www.choctaw.org/government/tribal_code/Title\%2026-\%20Uniform\%20Commercial \%20Code.pdf [https://perma.cc/CPM3-G7NX].

135. See 27 SAC \& Fox Nation Code OF Laws § 9-701 (2007), http://sacandfoxna tion-nsn.gov/sites/sfnation/uploads/documents/SF_CODES_Law/code_of_laws/27_ UCC_-_Article_9_-_Secured_Transactions.pdf [https://perma.cc/Z7TQ-RBXZ]. 
the principal chief; the Chehalis Tribe ${ }^{136}$ the Lac Courte Oreilles Band of Lake Superior Chippewa, ${ }^{137}$ the Muscogee Creek Nation, the Sac and Fox Tribe of the Mississippi in Iowa, ${ }^{138}$ and the Turtle Mountain Reservation ${ }^{139}$ require filings with the secretary of the tribe; the Hoopa Valley Reservation requires filings with the Tribal Department of Commerce; ${ }^{140}$ the Ho-Chunk Nation requires filings in the Nation's Land Records Office; ${ }^{141}$ and the Seminole Nation of Oklahoma requires filings with the Tribal Office of the Commission. ${ }^{142}$

- One tribe created a filing system specifically to take security interest filings: the Navajo Nation in Arizona. ${ }^{143}$

- Ten tribes either have no stated filing system in their law or their filing system is unknown: the Bois Forte Reservation, the Crow Creek Sioux Tribe, ${ }^{144}$ the Eastern Shoshone ${ }^{145}$ and Northern Arapaho $^{146}$ Tribes of the Wind River Reservation, the Keweenaw Bay Indian Community, Fort McDowell Yavapai Nation, ${ }^{147}$ the Oneida Nation, the Osage Nation, the Omaha Tribe, the Southern Ute Reservation, ${ }^{148}$ and the Yankton Sioux Tribe of South Dakota. ${ }^{149}$

136. See 9 Chehalis Tribe Code $\$ 9.25 .010$ (1995) (on file with Author).

137. See 12 Lac Courte Oreilles Band of Lake Superior Chippewa Indians Tribal Code $\S 16-21$ (2010) (on file with Author).

138. See Sac \& Fox Nation Code of Laws $\S 4-2101$ (2007) (on file with Author) (incorporating the UCC as adopted by the ULC).

139. See Turtle Mountain Band of Chippewa Indians Commercial Code $\S 24.4501$ (2012), https://www.tm.edu/wp-content/uploads/files/Academics/Paralegal \%20Resources/TITLE\%2024-Commercial.pdf [https://perma.cc/YY8V-Y5NR].

140. See 57 Hoopa Tribal Code $\S 2.101$ (1998), https://www.hoopa-nsn.gov/wpcontent/uploads/2015/06/Title57-CommercialTransactions062098.pdf [https:// perma.cc/5C57-9N82].

141. See 5 Ho-Chunk Nation Tribal Code $§ 7.4$ (b) (2005), https://ho-chunknation.com/wp-content/uploads/2019/10/5HCC7Uniform-Commercial-Code-Ordinance05.05.05.pdf [https://perma.cc/CX88-9HE5].

142. See 29 Seminole Nation of Oklahoma Code (2007), https://narf.org/nill/ codes/seminole_nation_ok/index.html [https://perma.cc/7PW5-F9KX].

143. See Bruton, supra note 65.

144. See generally Crow Creek Sioux Code (1997), https://narf.org/nill/codes/ crow_creek_sioux/index.html [https://perma.cc/Q3J4-FJX3].

145. See generally EAstern Shoshone Code (2004), https://www.windrivertribal court.com//wp-content/uploads/2018/05/Title_XIV.pdf [https://perma.cc/7F65-XPNL].

146. See generally Northern ArAPAHO CODE (2018), http://northernarapaho.com/wp/wp-content/uploads/2019/02/NA-Code-Title-18-UCC-Secured-Trans.-

Code-8-17-18-1.pdf [https://perma.cc/3869-NL3S].

147. See generally The Fort McDowell Yavapai Nation Law \& Order Code $\S 2-100$ (2015), https://www.fmyn.org/wp-content/uploads/Fort-McDowell-WordProofs-3-27-2015.pdf [https://perma.cc/EPQ5-VE8M].

148. See Hawkland ET AL., supra note 46, § 9-101:2.

149. See generally 9 YankTon Sioux Tribal Code (1995), https://narf.org/nill/ codes/yanktoncode/yanktoncodet9creditors.html [https://perma.cc/MCM9-S7KA]. 


\section{Scaling Economic Relationships and Tribal Sovereignty in Commercial Law}

In Part II, I laid out the uniformity and deviations that exist in tribal secured transactions laws. In this Part, I describe how scale and relational economic geography offer insights into tribal choices in this area. The starting point when thinking about how tribes interact with commercial laws is often their status as a separate sovereign. It is the status of tribes as sovereigns that creates the authority and the desire to facilitate economic conditions within their tribal territories. As Robert Miller notes, unemployment on Indian reservations (with rates between $20 \%$ to $80 \%$ ) challenges the structural capacity "for community building and for preserving a nation and a culture." 150 And it is the status of tribes as sovereigns that also dictates their desire to retain individual control over the structures and institutions that influence tribal life. While contested by scholars, economists, and Indian leaders themselves, some take the view that encouraging growth through financial institutions (capitalism) is an abrogation of the tribe's sovereignty. ${ }^{151}$

Model legislation on Indian tribes is designed to downscale uniform law to local levels. ${ }^{152}$ In turn, the effect is an upscaling of economic enterprise to have effects beyond the local level by replicating conditions that financial institutions have come to expect when lending money to individuals, businesses, and governments. Those conditions include ones that lower costs (and risks) associated with the lack of knowledge. In short, if everyone is playing by the same rules in the lending game, then the game is faster, cheaper, and more likely to have more players. The more deviations that are present introduce greater amounts of risk and uncertainty diminishing the likelihood of investment. Localism is one such deviation that has the effect of reducing the ubiquity of commercial law. Thus, understanding how tribes have implemented model legislation (that upscales economic growth opportunities) and how they have deviated from model legislation can highlight the fault lines for how tribes think about protecting their sovereignty. Similarly, understanding how the formal and organic relationships emerge in the face of these adoptions can further explain the tensions that tribes face relating to their sovereignty claims.

150. Miller, supra note 9, at 2.

151. See Aaron Drue Johnson, Just Say No (To American Capitalism): Why American Indians Should Reject the Model Tribal Secured Transactions Act and Other Attempts to Promote Economic Assimilation Comments, 35 Am. Indian L. Rev. 107 (2010). But see Miller, supra note 9, at 4 (quoting the Navajo Chairman and Oneida Principal Chief rejecting the line of thought that assumes embracing capitalism is a rejection of tribal legacies).

152. Johnson, supra note 151, at 107. 


\section{A. Scaling Secured Transactions Laws in Indian Country}

When looking at the way that secured transactions laws have been implemented, a scale analysis could help explain why some tribes may experience economic growth and some may struggle to realize economic opportunity.

\section{Downscaling Uniform Law in Indian Country}

When evaluating the approaches by Indian tribes toward secured transactions, the majority of tribes that have adopted a law have adopted some variation of a uniform law provision. Out of the sixtytwo adoptions I was able to discover, fifty have adopted either the ULC version of the UCC, the MTSTA, or have incorporated a state law on the UCC (which is built on the ULC's UCC). ${ }^{153}$ Tribes doing so are implicitly seeking to incorporate laws that other states and private actors have come to rely on in their dealings. Another way of scaling is by incorporating common mechanics for implementing the commercial law. Thus, when tribes utilize state filing systems (either under compact or informally) they scale-up the effectiveness of local transactions beyond the local context. The scaling of commercial law to local contexts operationalizes commercial resources by making access to the law more uniform. In turn, uniform law has the capacity to upscale idiosyncratic local transactions by joining the power of regional, state, national, and global actors who share common regimes and expectations for how commercial law is carried out. This upscaling of localized transactions is carried out with network effects that join the power of individuals and local communities with the lex mercatoria $^{154}$ that shapes actors and transactions in other places far from the local tribe. One approach that offers great potential for Indian tribes in this arena is the development of privatized filing systems, such as those suggested by William Henning and Susan Woodward, which would enable tribes to harness their collective power toward a greater collective benefit. ${ }^{155}$

The impulse toward harmonization in commercial law is such an old saw that it has become practically an inherent truth of commercial growth. ${ }^{156}$ What uniformity is attributed to is the law's best attempt to capture the norms of universal commercial practice and apply it to local contexts-not quite a lex mercatoria, but also not unbridled lo-

153. See infra Appendix.

154. See Gilles Cuniberti, Three Theories of Lex Mercatoria, 52 Colum. J. TransNAT'L L. 369, 373 (2013) (stating the general view of lex mercatoria as an autonomous transnational commercial law made up of customs and usages prevalent in commercial dealings).

155. See generally Henning, Woodrow \& Dubovec, supra note 13.

156. See John Linarelli, The Economics of Uniform Laws and Uniform Lawmaking, 48 Wayne L. Rev. 1387 (2002); Larry E. Ribstein \& Bruce H. Kobayashi, An Economic Analysis of Uniform State Laws, 25 J. Legal Stud. 131, 138 (1996). 
calized law with no connection to either commerce or other state approaches. ${ }^{157}$ Article 9 of the UCC is regularly heralded as the most successful of the ULC's projects for its ability to promote uniform approaches to secured lending. ${ }^{158}$ And even in the moments when its lack of uniformity was an obstacle to its adoption, the reframing of the Article to achieve a uniform approach in the face of state reluctance to adopt fixture provisions ultimately proved to be a source of its importance in the world of commercial dealing. ${ }^{159}$ That uniformity, even if in name only, bolsters confidence and promotes stability in the realm of commercial law dealings. The choice to adopt uniform laws can be seen as a rhetorical aligning of general principles to tribal practices.

What uniformity then "scales" is the replication of regimes in smaller contexts that broaden access to resources that otherwise exist outside of local regions. Commercial law has shown an uncanny ability to replicate itself over and again regardless of the scale size in which it is applied. For example, international conventions on secured finance have broadened the scope of Article 9's content to a global context. ${ }^{160}$ A tribe's choice to adopt uniform approaches to secured transactions is an explicit attempt to reach beyond the local barriers that may exist and seek out a common commercial practice.

\section{Localizing Commercial Law Efforts on Indian Tribes}

Despite the potential that uniformity offers in upscaling local commerce to larger streams of resources, tribes can reduce the effect of uniformity through local interventions. Current tribal practices in secured transactions reveal four ways that local practices interfere with uniformity. The most obvious way that tribes assert localized variations in commercial law is by adopting non-uniform provisions. As noted in part one, several tribes have adopted non-uniform laws that relate to security interests. These inherently non-uniform provisions draw territorial maps around the tribe that signal to lenders that business is not as usual within tribal lands.

A second local intervention away from uniform approaches to commercial law is by limiting the types of transactions that the law can be used for. For example, several tribes have adopted a secured finance law that only applies to sales of accounts and chattel paper. While these provisions are important (arguably the most important innova-

157. See Cuniberti, supra note 154 , at 150 .

158. Henning, Woodrow \& Dubovec, supra note 13, at 483.

159. See Marc L. Roark, "Opening the Barbarians' Gate" or Watching the Barbarians from the Coliseum: A Requiem on the Nomos of the Louisiana Civil Law, 67 LA. L. Rev. 451, 483 (2006); Marc L. Roark, Groping Along Between Things Real and Things Personal: Defining Fixtures in Law and Policy in the UCC, 78 U. CIN. L. Rev. 1437, 1499 (2009).

160. Henning, Woodrow \& Dubovec, supra note 13, at 478-79. 
tion of Article 9), limiting transactions to only this subset restricts the power of the law to attract finance to tribes for the overall economic well-being of all persons. Likewise, tribes assert localized control over commercial settings by limiting the actors that can access the law. Nine tribes have adopted provisions that limit the law's effects to either tribal enterprises, the tribe itself, or to non-consumer transactions. ${ }^{161}$ Like limiting the type of transaction that the law covers, these provisions create local barriers to its effectiveness. The adage that a rising tide lifts all boats then rings hollow when some boats cannot access the water.

Finally, tribes localize commercial law by isolating their filing systems from either other tribes or from the state where they are located. Filing systems themselves are scaled productions of the law. They are scaled because they extend the power of a collective practice to local regions, while expanding the kinds of resources that local regions have access to. The idea of a filing system is that it represents convenient locations where creditors can gather information about debtors they seek to do business with. Filing systems upscale the resources that are otherwise unavailable on tribal lands by gathering in convenient locations information that lenders deem necessary to conduct business. By making that information universally accessible, filing systems create networks of lending operations supported by local law. The broader and more complete the filing system, the more likely that lenders will see the transaction as not imposing additional barriers.

Consider, for example, the Montana filing system with the Crow tribe. ${ }^{162}$ The value of the system is that lenders can gather a more complete picture relating to debtors in a single location rather than

161. See, e.g., Secured Transactions Ordinance of Bay Mills Indian ComMuNity $§ 1$ (1994); 1 Blackfeet CoMmercial Code $§ 2$ (1990), https://www.narf. org/nill/codes/blackfeetcode/ord81.pdf [https://perma.cc/9TN6-PQZ3]; 9 CHEHALIS Tribe OF WAshington CODE $\$ 9.25 .050$ (2020), https://www.codepublishing.com/ WA/ChehalisTribe/\#!/ChehalisTribe09/ChehalisTribe0925.html\#9.25.080 [https:// perma.cc/5UKL-6CZD]; 2 Eastern Band of Cherokee Indians Tribal Code $\S 16 D-1(a)$ (2001), https://library.municode.com/tribes_and_tribal_nations/eastern_band_of_cherokee_indians/codes/code_of_ordinances?node $\bar{I} d=P T \bar{I}$ _COOR CH16DUCORTRCAGAEN_S16D-1ADAR19 [https://perma.cc/924K-YNRT]; 12 Waganakising Odawak Tribal Code $\$ 12.203$ (2020), https://www.ltbbodawansn.gov/TribalCode.pdf [https://perma.cc/N7FF-USHD]; ForT MCDowell YAvAPAI NATION LAW \& ORDER CODE § 2-100 (2006), https://www.fmyn.org/tribal-government/law-and-order-code/ [https://perma.cc/5PQB-5XQN]; 43 PoArch CREeK INDIAN LAW \& ORDER CODE \& 43-1-1 (2020), https://library.municode.com/ tribes_and_tribal_nations/poarch_band_of_creek_indians/codes/code_of_ordinances ?nodeId=TIT43SETR_CHISETR_S43-1-1PU [https://perma.cc/E64K-6Z37]; PonCA Tribe of Nebraska Law \& OrDer Code $\$ 13-3-1$ (2018), https://www.poncatribene.org/wp-content/uploads/2020/05/law_codetitle_v13_050120.pdf [https://perma.cc/ B88W-ZGQM]; SAN Manuel Tribal Code $\$ 25.5$ (2016), https://www.sanmanuelnsn.gov/portals/1/TribalGovernment/TribalLaws/San_Manuel_Secured_Transactions_ Ordinance_Amended_July_12_2016.pdf [https://perma.cc/C8GF-BVGK]; see also Hawkland ET AL., supra note 46, § 9-101:2.

162. See Crow Nation, State of Montana Sign UCC Filing Compact, supra note 94. 
having to allocate resources to learn idiosyncratic systems that have few filings. Thus, if the Crow tribe's eighty-seven filings were contained on tribal lands, rather than in the secretary of state's filing system, lenders may shy away from doing business on the tribe. When filing systems are increasingly isolated from other normal practices, or are not easily accessible, creditors will be more likely to bypass doing business where those systems are necessary. One advantage that the Henning and Woodward approach to a privatized filing system offers is the capacity to scale up the filing systems for multiple tribes while reducing the costs and complexity that tribes ordinarily would have to undertake to make a filing system work. ${ }^{163}$ The tradeoff, though, is that tribes lose a certain level of control over the way the filing system is maintained.

\section{B. Relational Structures Through Commercial Law}

The deviations laid out in the Section above suggest that tribes may realize limited gains from commercial laws when they deviate from certain uniform practices. Notably, the creation of non-uniform filing systems is a major barrier to the successful implementation of these laws, though other limits that I pointed out certainly have similar limiting effects. Because the adoption of secured transactions laws on Indian tribes takes place in particular places, and those places have relationships to individuals, entities (such as states and tribes), and resources, it is helpful to think about the adoption of these laws in this context.

Economic geography can offer insights into some of the relevant questions that non-uniformity may present. Economic geography is the study of the location, distribution, and spatial organization of economic activities across the world or in specific regions. ${ }^{164}$ Relational economic geography focuses on the role of individual or institutional relationships within a proximity for understanding economic relationships. ${ }^{165}$ Relational economic geography has been criticized for its lack of precision and tendency to oversimplify causes and relationships relating to economic phenomenon; ${ }^{166}$ and for the view that the relations described are adequately explained by other pre-existing theories. ${ }^{167}$ The critiques have been built on the imprecision that relationships are defined within the literature. For example, Peter Sunley

163. Henning, Woodrow \& Dubovec, supra note 13, at 498.

164. The Oxford Handbook of Economic Geography (Gordon L. Clark, Maryann P. Feldmann \& Meric S. Gertler eds., 2000).

165. See Peter Sunley, Relational Economic Geography: A Partial Understanding or a New Paradigm?, 84 ECON. GeOgraphy 1, 4 (2008).

166. Id. at 15 .

167. Henry Wai-chung Yeung, Rethinking Relational Economic Geography, 30 Transactions Inst. Brit. Geographers 37, 46 (2005). 
points out that relational concepts have been applied in multiple ways in the economic geography literature lending toward its imprecision:

Relational has a dual meaning, ranging from specific forms of relationships to any exchange, agreement or interaction between two or more people and this dual meaning has caused considerable confusion .... The first has developed from economic sociology and typically understands relational as signifying interpersonal and interorganizational networks and connections of a certain type. The second is linked to post-structuralist thought and uses relational more broadly to point to the significance of all forms of networks and relations between entities. ${ }^{168}$

In short, relational theories at their worst over-emphasize regional phenomenon to the exclusion of other contextual factors to explain why certain regions do poorly and others succeed. ${ }^{169}$

However, that does not mean that economic geography that recognizes relational components is unhelpful in understanding specific economic trends. In this context, "relational" can be precisely defined to mean "specific mode[s] of economic coordination or governance based on strong ties and long-term, reciprocal relationships." 170 The literature then presents two distinctive types of relationships and their impacts on economic success-one being an embedded, organic, natural relationship which is stylized as "informal, self-enforcing, and sustained by the value of future relationships," premised on the potential for future investment that cannot be predicted. ${ }^{171}$ The second is a highly formalized, impersonal relationship that is premised on the basis of social ties and arm's length bargaining. ${ }^{172}$ In the former, the relationship is defined by the proximity of resources, the low barriers individual actors face in utilizing those resources, and the interpersonal connections that can be leveraged in carrying out economic activity. Here, insiders tend to prevail due to the intimate knowledge they have gained by being present and gaining the knowledge of their surroundings. In contrast, where the relationship is formalized, economic activity is atomistic, ritualized, and impersonal, and is primarily driven by profit seeking and opportunism. ${ }^{173}$

Tribal adoption of laws relating to commercial practice reflects formal relationships within the tribe. Governmental tribes can formally adopt laws and treaties designed to facilitate economic growth. For example, the emergence of model codes designed to import common commercial language and practices into tribal communities stems from a formalized power of the tribal government to enact laws for

168. Sunley, supra note 165 , at 4.

169. Yeung, supra note 167, at 46.

170. Sunley, supra note 165 , at 4.

171. Id.

172. $I d$.

173. $I d$. 
the tribe's wellbeing. One reason for the emergence of these laws is the concern that the embedded (organic) recognition of tribal selfgovernment is a barrier to doing business in Indian Country. ${ }^{174}$

In this context, economic relationships overlap across formal and informal associations in the context of efforts to promote economic growth on Indian tribes. Indian tribal governments represent highly formalized and artificial governing structures over the interests of Indian peoples. ${ }^{175}$ Tribal governments are organized and formalized through structures imposed by the Bureau of Indian Affairs and established by tribes themselves and contain both formalized and geographic criteria. Tribal sovereignty suggests that tribes may dictate their own form of government as they see fit. Thus, tribal governments range from highly sophisticated forms of government with three branches of government, human services agencies, and thick bureaucracy, to tribal governments that lack any or all of those traits. Likewise, the formalized structures emerge through a process of formalization and recognition by the U.S. government of the tribal government's authority. ${ }^{176}$ The recognition can happen by legislation, a federal court decision, or by complying with the federal acknowledgement process.

The geographic resources available to tribes, on the other hand, are more organic. While natural relationships amongst people associated to tribes emerge and are formalized over time, ${ }^{177}$ the geographic relationship of people, tribes, and resources dictate access individuals and communities have to economic resources. The access (or lack of access) to resources shapes formal responses by tribes and states. For example, some Indian tribes' lack of lending infrastructure has prompted trade groups, federal offices, tribes, or states to enact measures to facilitate conditions that would prompt greater access to capital. ${ }^{178}$ Additionally, Indians living on reservations suffer much higher rates of poverty $(28.4 \%)$ than the national average $(12.7 \%),{ }^{179}$ and

174. Berg, supra note 74 , at 32.

175. Richard Loudbear, Indian Country Politics: Theories of Operation and a Strategy for the Nonviolent Seizure of Political Power, 31 Am. Indian Q. 66-86 (2007).

176. Curtis Berkey, Implementation of the Indian Reorganization Act, AM. INDIAN J. 2, 6 (1976).

177. E. Cheyfitz, Savage Law: The Plot Against American Indians in Johnson and Graham's Lessee v. M'Intosh and The Pioneers, in Cultures of United States IMPERIALISM 109-28; Eric Cheyfitz, The (Post)Colonial Construction of Indian Country: U.S. American Indian Literatures and Federal Indian Law, in The Columbia Guide to American Indian Literatures of the United States Since 1945116 (Eric Cheyfitz ed., 2006); Adam Crepelle, Decolonizing Reservation Economies: Returning to Private Enterprise and Trade, 12 J. Bus. Entrepreneurship \& L. 413, 426 (2019).

178. Henning, Woodrow \& Dubovec, supra note 13, at 476.

179. Jessica L. Semega, Kayla R. Fontenot \& Melissa A. Kollar, Income and Poverty in the United States: 2016, U.S. Census Bureau 1, 2 (Sept. 2017), https:// www.census.gov/content/dam/Census/library/publications/2017/demo/P60-259.pdf [https://perma.cc/WF7A-W533]. 
higher rates than found amongst Indians as a whole (22\%). ${ }^{180}$ The poverty experienced by Indians on reservations has roots in both formalized structural and informal organic sources relating to the geography of exclusion. ${ }^{181}$ Like other minority groups in the United States, the extent of inequality often has roots in historically accumulated disadvantage. That disadvantage started through formal structures that provided for removal of Indians from their ancestral homes. The disadvantage compounded thanks to the poor quality of the land that they were given to inhabit, limiting their access to resources (organic relationship to the land). ${ }^{182}$ There is also a more organic recognition embedded in U.S. law of tribal self-government. Federal courts have consistently recognized tribal self-government as a recognition of their inherent original sovereignty, even if often undoing the tangible realities of that sovereignty. ${ }^{183}$ Tribal sovereignty reflects that Indian selfgovernment does not stem from federal recognition but rather by reason of their original tribal sovereignty. ${ }^{184}$ The implications of self-government are expressed through treaty-making power and through sovereign immunity protection. ${ }^{185}$

These formalized and organic relationships emerge in specific regions that help shape and contextualize how economic relationships are developed. Tribes themselves exist in specific territories. For instance, tribes with separate sovereigns are organized across boundaries that are either wholly within one state or across a few states. ${ }^{186}$ Some of those territorial relationships are formalized, like in the definition of Indian Country in federal statute ${ }^{187}$ or in stances where tribes and states enter into treaties or compacts for mutual coordina-

180. American Indian and Alaska Native Heritage Month: November 2011, U.S. Census Bureau (Nov. 1, 2011), https://www.census.gov/newsroom/releases/archives/ facts_for_features_special_editions/cb11-ff22.html [https://perma.cc/RE4N-NWJR].

181. David Sibley, Geographies of EXClusion?: SOCIETY AND DIFFERENCE IN THE WeST 9-10 (1995).

182. James J. Davis, Vincent J. Roscigno \& George Wilson, American Indian Poverty in the Contemporary United States, 31 Soc. F. 5,6 (2016).

183. See, e.g., Talton v. Mayes, 163 U.S. 376, 381 (1896); Williams v. Lee, 358 U.S. 217 (1958); Native Am. Church v. Navajo Tribal Council, 272 F.2d 131 (10th Cir. 1959).

184. Tribal Self-Government and the Indian Reorganization Act of 1934, 70 МicH. L. REV. 955, 955 (1971).

185. Kunesh, supra note 4, at 398.

186. The four corners tribes in Utah, Colorado, New Mexico, and Arizona are a key example.

187. 18 U.S.C. $\S 1151$ (2020) and 40 C.F.R. $§ 171.3$ (2020) define Indian Country as:

a. all land within the limits of any Indian reservation under the jurisdiction of the United States Government, notwithstanding the issuance of any patent, and, including rights-of-way running through the reservation;

b. all dependent Indian communities within the borders of the United States whether within the original or subsequently acquired territory thereof, and whether within or without the limits of a state; and

c. all Indian allotments, the Indian titles to which have not been extinguished, including rights-of-way running through the same. 
tion or cooperation. ${ }^{188}$ The relationships that emerge among tribe members, between tribes and states, and between tribes and interstate organizations are more formalized across geographic resources. ${ }^{189}$

Evaluating the effectiveness of specific measures designed to expand economic activity on Indian tribes is one that appears to be more of an art than a science. One reason for that is the overlap between formalized structures and organic limitations that each have independent impacts on tribal economic growth. For example, tribes in the Great Plains are typically less prosperous than tribes in other areas of the United States Tribes that have more sophisticated forms of government, such as tribal court systems, are more economically prosperous than those with more basic forms of government. ${ }^{190}$

Two researchers published in the American Indian Quarterly a list of potential obstacles to tribal economic growth. ${ }^{191}$ These barriers offer a mix of examples of how formal and organic relationships can limit economic growth. For example, the list begins with the fact that "tribes and individuals lack access to financial capital."192 This is an organic relationship because it reflects the status of tribal economic resources that are available to tribes and tribal members in particular locations. At the same time, it is something that the creation of formal relationships through the adoption of tribal secured transactions laws attempts to remedy. 193

The adoption of systems similar to Article 9 interacts with other formal and organic limitations present on Indian tribes. For example, a secured transactions system requires different levels of state bureaucracy, such as filing offices or compacts with nearby state offices. ${ }^{194}$ Secured transactions also require manpower, organizational capacity,

188. For example, the Crow Nation and the State of Montana entered into a compact in 2008 for the joint use of the state's filing system to facilitate secured transactions laws in tribal territory.

189. Thomas Biolsi, Imagined Geographies: Sovereignty, Indigenous Space, and American Indian Struggle, 32 Aм. EтhNOLOGIST 239-59 (2005); ScOTt, supra note 25; Cheyfitz, supra note 176; Robert J. Miller, Inter-Tribal and International Treaties for American Indian Economic Development Symposium: Indigenous Economic Development: Sustainability, Culture, and Business, 12 Lewis \& Clark L. Rev. 1103-34 (2008).

190. Stephen Cornell \& Joseph P. Kalt, Sovereignty and Nation-Building: The Development Challenge in Indian Country Today, 22 Am. Indian Culture \& Rsch. J. 187 (1998); Stephen Cornell \& Joseph P. Kalt, What Can Tribes Do? Strategies and Institutions in American Indian Economic Development, 18 AM. Indian Q. 250 (1994) [hereinafter Cornell \& Kalt, What Can Tribes Do?].

191. Cornell \& Kalt, What Can Tribes Do?, supra note 190.

192. Id. at 6 .

193. Id. at 8 .

194. Marc L. Roark, Secured Transactions Behind the Buckskin Curtain, Hoover Inst. 1, 7 (2019), https://www.hoover.org/sites/default/files/marc_roark.pdf [https:// perma.cc/US6R-5NDN]. 
and resources to make the system searchable. ${ }^{195}$ Developing secured transactions systems on an individual basis by tribes would require not only manpower, but also expertise and financial resources. Bill Henning, Susan Woodrow, and Marek Dubovec's proposal of a privatized nationwide filing system that tribes could subscribe to that would close the resource gap necessary to implement an Article 9-like system, while making access to financing information more ubiquitous for creditors and debtors (and researchers) alike, is one approach to closing the resource gap that has been identified as a barrier. ${ }^{196}$

What efforts like the MTSTA and privatized filing systems attempt to replicate is the manufacture of "institutional thickness" where previously absent. Institutional thickness reflects on the presence of institutional interaction, coalition building, and the emergence of common mission or enterprise within regions. ${ }^{197}$ Institutional thickness emerges from the confluence of both formalized associations and naturally occurring relationships that can be harnessed toward common goals. Research on rural places and institutional thickness suggests that the stakeholder impact of local elites may have a significant impact on the development of other factors that would facilitate an institutionally thick setting. ${ }^{198}$ Tribal respect for elders and other traditional stakeholders may hold similar sway in the creation (or stymie) of institutions in Indian Country.

This Part unpacks how institutional thickness is furthered through the facilitation of secured transactions in Indian Country. Specifically, I focus here on the emergence of both formal relationships, from sov-

\section{Id.}

196. Henning, Woodrow \& Dubovec, supra note 13. The original plan for this paper was to use filing systems to evaluate utilization of secured filing systems in tribal communities. However, the fact that tribes have either not set up tribal filing systems on their own merit or have, in the alterative, contracted with local state partners for joint filing systems made that research plan impracticable. The fact that states do not have a way to segregate filing systems also rendered that plan unfeasible. The point here is that the inefficiencies for mining data relating to tribes do not merely rest on tribes but also rest on states whose systems are less than optimal for ascertaining this information.

197. Amin Ash \& Nigel Thrift, Living in the Global, in Globalization, Institutions, and Regional Development in Europe (Amin Ash \& Nigel Thrift eds., 1996); Alun Jones \& Julian Clark, Of Vines and Policy Vignettes: Sectoral Evolution and Institutional Thickness in the Languedoc, 25 Transactions Inst. Brit. GeOGRAPHERS 333, 333-53 (2000).

198. Jones \& Clark, supra note 197; Stephanie Lee Black \& Carolyn Birmingham, American Indian Leadership Practices, in AMERICAN Indian Business 125-26 (Deanna M. Kennedy et al. eds., 2017); Clint Carroll, Conclusion. Sovereign Landscapes: Spiritual, Material, and Political Relationships to Land, in Roots of OUR Renewal 171-82 (2015); Kathy Davis Graves \& Elizabeth Ebbott, Shifting Governmental Relationships, in Indians In Minnesota 18 (5th ed. 2006); Clint Carroll, The Spirit of This Land: Terrains of Cherokee Governance, in Roots OF Our Renewal 140-41 (2015); Andrew M. Miller \& Iain Davidson-Hunt, Agency and Resilience: Teachings of Pikangikum First Nation Elders, Northwestern Ontario, 18 Ecology \& Soc'y (2013); Angela R. Riley, Good (Native) Governance, 107 CoLu. L. Rev. 1049, 1119 (2007). 
ereign arrangements such as compacts for filing systems and crosslateral tribal network effects that influence growth, and the emergence of organic relationships, such as the presence of financial institutions in Indian Country, that relate to secured transactions adoptions in Indian Country.

\section{Formal Relationships}

The steps that Indian tribes have taken toward formalizing relationships with neighboring states and with actors that would come into Indian Country to do business is partly due to the hostility that federal courts have treated Indian sovereign claims in recent years. ${ }^{199}$ As previously noted, early federal court decisions affirmed that Indian tribes enjoyed separate status as sovereigns even after first contact. ${ }^{200}$ But as one scholar noted, the federal courts in recent years have shown a willingness to bend away from traditional bedrock principles of tribal sovereignty and more toward non-Indian interests. ${ }^{201}$ Public Law 280 made tribal jurisdiction ambiguous where state courts have asserted jurisdiction over certain matters. ${ }^{202}$ Thus, in an effort to preserve the footing that tribes have held under sovereignty principles, federal courts have tended to formalize through compacts and adoptions of laws waiving sovereignty in limited contexts or through preserving tribal court jurisdiction to preserve the overall breadth of sovereignty claims.

Creating formalized relationships through treaties and compacts can have a Janus-like ${ }^{203}$ reality for Indian Tribes. On the one hand, the treaty and compact process reiterates that tribes and states are on equal footing as sovereigns, capable of administering and governing in

199. Richard J. Ansson, Jr., State Taxation of Non-Indians Whom Do Business with Indian Tribes: Why Several Recent Ninth Circuit Holdings Reemphasize the Need for Indian Tribes to Enter Into Taxation Compacts with Their Respective State, 78 OR. L. REv. 501, 503-04 (1999); Kunesh, supra note 4, at 398-400; David H. Getches, Conquering the Cultural Frontier: The New Subjectivism of the Supreme Court in Indian Law, 84 CAL L. Rev. 1573, 1576, 1627 (1996); Intergovernmental Compacts in Native American Law: Models for Expanded Usage, 112 HARv. L. Rev. 922, 922-23 (1998). 200. Robert A. Williams, The American Indian in Western Legal Thought: The Discourses of Conguest (1990); Crepelle, supra note 177, at 143; Kunesh, supra note 4, at 416; Biolsi, supra note 189, at 242; Getches, supra note 199, at 1599; Ansson, supra note 199; Graves \& Ebbott, supra note 198.

201. Getches, supra note 199, at 1573.

202. Codified as 18 U.S.C. $\S 1162$ and 28 U.S.C. $\S 1360$.

203. The term Janus-like, meaning two-sided, draws on the ancient Roman god Janus, who was depicted with two faces as he looked to both the future and the past. The two-fold Janus embodies many dualisms but none so prevalent as how the deeds of the past shape the markings of the future. "Put aside your fear and learn, laboring poet of the days, what you seek, and mark my words in your mind. The ancients called me Chaos (for I was the first thing). Behold the deeds of a long age which I sing." Erik, Who Is Your Janus and What Does He Do?, Sententiae Antiquae (Jan. 2, 2020), https://sententiaeantiquae.com/2020/01/02/who-is-your-janus-and-what-doeshe-do/ [https://perma.cc/ZV3F-AZ55] (translating Ovid, Fasti I.63-I32). 
their respective territories. On the other hand, despite these rehearsals and formalized acknowledgements of tribal self-determinacy, the history of Indian law is replete with deals that are one-sided and lack bargaining that is reflective of co-equals. ${ }^{204}$ As one scholar notes, the traits of Indian bargaining were stylized through formal recitations of co-equals sitting at the bargaining table, while the stark reality was that bargaining was conducted under threat of the sword. ${ }^{205}$ Thus, we should not be surprised that the majority of tribes have responded with skepticism toward the expansion opportunity that limiting their sovereignty or bargaining for cooperation in contexts of commercial expansion provide. As the saying goes: been there, done that.

Likewise, the status of tribes as a sovereign (with recourse to all remedies that a sovereign would expect-like sovereign immunity) is so tied to Indian identity that waiving claims to sovereignty is no light matter. Bob Miller emphasizes the care that businesses dealing with tribal governments should take when dealing with immunity claims: "[t]ribes expect to have their sovereign status and immunity powers taken seriously .... Consequently tribes are understandably concerned about being asked to waive these ... powers for every minor business deal." 206

Still, the desire to further economic growth in Indian Country has prompted tribes to pursue opportunities that will expand businesseven at the expense of their own sovereignty claims in some instances. Indeed, as Part I describes, at least 64 tribes-out of the 573 federally recognized tribes-have adopted some form of secured transactions law. In building the infrastructure necessary to facilitate these laws, tribal measures represent a range of approaches from either highly formalized arrangements through state compacts to no formal structure at all. Below, I focus on the role of Indian-state compacts in furthering "institutional thickness" and the role of formal waivers of sovereign immunity in commercial codes as steps toward building formal relationships and enhancing thickness.

\section{a. Manufacturing Institutional "Thickness" Through Compacts with States}

One example of formalized relations on Indian tribes is the use of compacts with neighboring states. Compacts have been used in several settings including agreements on taxation of cigarettes and gasoline, ${ }^{207}$ water rights ${ }^{208}$ gambling, ${ }^{209}$ motor vehicle registrations,${ }^{210}$ and sacred

204. Graves \& Ebbott, supra note 197; Allan Greer, Dispossession in a Commercial Idiom: From Indian Deeds to Land Cession Treaties, in Contested Spaces of EARLy America 69-71 (Juliana Barr \& Edward Countryman eds., 2014).

205. Greer, supra note 203, at 69-71.

206. Miller, supra note 9.

207. Ansson, supra note 198, at 547.

208. See In re The Crow Water Compact, 354 P.3d 1217, 1218 (Mont. 2015). 
sites to name a few. In the commercial setting, state compacts relating to filing statutes and title registry statutes have facilitated formalized relationships between states and tribes toward creating thicker commercial laws in Indian Country.

As noted in Part I, three states (Montana, South Dakota, and Minnesota) have negotiated compacts with local tribes for the administration through the state's secretary of state office for filings under the tribe's secured transactions laws. ${ }^{211}$ Notably, the laws themselves are not necessarily uniform, and reflect different stages of development by tribes adopting secured transactions laws. For example, the Cheyenne River Sioux in South Dakota's laws incorporate South Dakota's UCC into tribal law, ${ }^{212}$ whereas the Oglala Sioux have adopted the MTSTA into tribal law. ${ }^{213}$ Similarly, in Montana, the Blackfeet Tribe has incorporated the ULC's UCC into tribal law, ${ }^{214}$ whereas the Crow Tribe has adopted the MTSTA. ${ }^{215}$ One might argue that the differences between all of these laws are negligible since the MTSTA is based on the ULC's UCC, which is also the source of South Dakota's secured transactions law. Nevertheless, what it demonstrates is that different tribes chose different approaches to secured transactions within their tribal territory and yet chose similar ways to facilitate the administrative necessities for implementing the law in the same way.

The thickness that these tribal compacts represent are part and parcel with the expertise and bureaucracy required to effectively maintain a tribal filing office. An effective filing system must provide efficient means for both the filing and searching of lien recordings. ${ }^{216}$ Filing financing statements and lien statements requires not only the administrative expertise to develop the filing instrument that captures the information required under the secured transactions law, but also the technical expertise to make those forms or resources readily available to individuals who would file a financing statement in the system. Creditors using the system seeking to verify their priority status adds another dimension of expertise and technological capacity in the in-

209. Matthew L. M. Fletcher, Bringing Balance to Indian Gaming, 44 HARV. J. ON LEGIS. 39, 39 (2007).

210. Motor Vehicle Licensing Compact Between the Cherokee Nation and the State of Oklahoma for Lands Located Outside the Compact Jurisdictional Area of the Cherokee Nation, Cherokee Phoenix 1, 1 (Sept. 1, 2013), https://www.cherokeephoenix. org/Docs/2013/8/7512_cou_130813_MotorVehicleCompact2.pdf [https://perma.cc/ R8GK-6B9N].

211. Henning, Woodrow \& Dubovec, supra note 13, at 491. Additionally, while no formal compact exists, the Seminole Tribe utilizes the Florida Secured Registry as authorized by Florida statute.

212. See infra Appendix.

213. See infra Appendix.

214. 1 Blackfeet Commercial Code (1990), https://www.narf.org/nill/codes/ blackfeetcode/ord81.pdf [https://perma.cc/9TN6-PQZ3].

215. See infra Appendix.

216. Henning, Woodrow \& Dubovec, supra note 13, at 478. 
dexing of filings. Indexing filed records is crucial for the administrative effectiveness of a system because it permits searchers to easily discover records associated to either property or debtors, depending on the nature of the system. ${ }^{217}$

The thickness that is produced by these systems is also created through the formal associations between tribes and their states. Those formal relationships communicate to creditors seeking to do business on tribal lands that the processes that they are familiar with from other in-state transactions will remain static in Indian Country. To this end, the formalizing association also creates a network effect (organic relationship) which I will discuss in more detail below.

\section{b. Waivers of Sovereign Immunity Relating to Commercial Claims}

Just as the creation of formal relationships with state filing offices facilitates a "thickness" around the mechanics to maintain a filing system, Indian tribal waivers of sovereignty also reflect the status of formal relationships that might otherwise discourage financial actors from doing business in Indian territory. The standard provision in the MTSTA balances the importance of tribal self-determination, while providing the possibility that tribes could waive their sovereign immunity in a properly ratified record. ${ }^{218}$ Still, some tribes have adopted a non-uniform approach designed to give tribal actors the freedom to set limits for how they waive tribal immunity if it is in their best interest. $^{219}$

217. Id. at 493.

218. Nat'l Conference of Comm'rs on Unif. State Laws, Model Tribal SeCUREd Transactions Act § 9-102 (2006) ("No Waiver of Sovereign Immunity: The Sovereign Immunity of neither this [Tribe] [Nation] nor of any of its agencies or instrumentalities is waived with respect to any provision of any transaction sub.").

219. See 18 Northern Arapaho Code § 9-102 (2018), http://northernarapaho. $\mathrm{com} / \mathrm{wp} / \mathrm{wp}$-content/uploads/2019/02/NA-Code-Title-18-UCC-Secured-Trans.-Code-817-18-1.pdf [https://perma.cc/3869-NL3S].

Section 9-102 - Waiver of Sovereign Immunity; Presumption as to Limitation of Waiver.

(1) The sovereign immunity of the Northern Arapaho Tribe (Tribe) and/or any of its respective agencies or instrumentalities is not waived with respect to any provision or any transaction subject to this Code, absent a recorded, properly ratified, express waiver of sovereign immunity by resolution or ordinance of the Tribe specifically stating its intention to waive such sovereign immunity.

(2) Any waiver of sovereign immunity meeting the requirements of subsection (1) shall be presumed, except to the extent the written waiver expressly provides otherwise, to be:

(a) Granted only to the Northern Arapaho Tribal Court or other Tribal Court duly authorized by the Tribe;

(b) Limited in scope to monetary relief, not to exceed the amount of the contract regarding which performance is secured; and 
The balance between reaffirming tribal sovereignty and the potential for an effectively negotiated waiver is a signal to commercial actors seeking to do business with the tribe that the tribe will not use its privilege to deny properly negotiated contractual agreements. ${ }^{220}$ These provisions could be seen as invitations to the business community to create greater formal ties by alleviating concerns that they may not have a remedy if business goes south. While tribes expect that businesses will respect the tribe's status as a sovereign, they have also shown a willingness to waive immunity in contractual dealings. ${ }^{221}$

\section{Organic Relationships}

Just as formalizing relationships contributes to institutional thickness, so too does the existence of organic relationships that draw on common resources. One example of these types of relationships are those that exist because of geography or tribal affiliation, rather than formal associations. Thus, while the creation of tribal-state compacts for filing systems is a formal relationship, there is also an organic component since those tribes are located in states that are receptive to filing compacts. Organic relationships toward tribal secured transactions can be observed in both the impact of networks that emerge through legal adoptions and the resources that may be available for tribes to draw on. This network effect built on proximity can be extended in other ways when we consider the effect of secured transactions laws in Indian Country.

How Indian tribes adopt secured transactions laws in the first place is a fruitful area for exploration in future projects. For instance, several tribes and individuals with inside knowledge about how tribal communities adopted secured transactions laws pointed to the role of "influencers" in shaping tribal decisions to create these laws. Sometimes these influencers may be formal associations, such as with the Department of the Interior, which encouraged Indian tribes through financial grants to participate in the drafting process. ${ }^{222}$ Sometimes, the influence is more organic, such as when an insider on the tribe learns about the law and advocates for tribal adoption. ${ }^{223}$ As Hadley Louise Friedland suggests in the context of the Cree Tribe, tribal prac-

(c) Authorization of foreclosure only upon collateral expressly pledged as security.

Id.

220. Miller, supra note 9.

221. Id.

222. Elaine A. Welle, A Guide to the Model Tribal Secured Transactions Act for Those Familiar with the Uniform Commercial Code, 37 Am. Indian L. Rev. 467, 468 (2013).

223. Miriam Jorgensen \& Daniel Stewart, Creating Private Sector Economies in Native America: Sustainable Development Through EntrepreNEURSHIP 106 (Robert J. Miller ed., 2019). 
tice is well suited for the role of influencers to help steer how tribal governance is carried out. ${ }^{224}$

Another way that organic resources influence tribal secured transactions laws is the network effect of multiple similar laws in close geographic regions. This network effect is when tribes in common regions adopt similar regimes for facilitating secured transactions. Tribes that incorporate their local UCC provisions neutralize formal barriers that may exist between tribes, regions, and economic actors. When multiple tribes adopt the same law, the power of numbers reinforces the symmetries that may exist between states and tribes. This explains why relatively few tribes have adopted non-uniform provisions, instead opting for either the ULC version of the UCC, the MTSTA, or a state-based UCC version. Likewise, all of the tribes that have adopted secured transactions laws in Michigan and all but one of the tribes that have adopted secured transactions laws in Washington have incorporated their state's UCC law. ${ }^{225}$ Further, all of the tribes in Wisconsin that have adopted a secured transactions law have adopted a secured transactions law that is based on a ULC version of the UCC-either a state incorporation, the ULC's UCC, or the MTSTA. ${ }^{226}$ While these geographic similarities may not be intentional amongst the tribes, they do suggest that there are common resources that the tribes value that are reflected in the common approach to adopting a secured transactions law. A deeper ethnographic dive into how tribes adopted uniform provisions is a next step toward unpacking these questions.

A third way organic relationships emerge in the context of facilitating secured transactions is in the resources that are available to facilitate the laws. As noted above, the maintenance of a tribal filing system is a significant undertaking requiring both manpower, expertise, and spatial resources. A vast majority of tribes have approached this problem by informally using state filing systems to record financing statements. 227 Those tribes that maintain their own filing system opt for greater control over the filing systems that are so important in the Article 9 world over the network effects that drawing on regional filing systems can facilitate.

In addition to the resources available to facilitate a secured transactions law, tribes also face a "lending desert" that impacts the thickness of the institutional markets. Back in 2000, an article in Region Magazine highlighted the problems of banking access in Indian Country, noting the prevalence of thirty-mile drives and non-existent ATM machines. Drawing on an advocacy group's term, the article labeled the

224. See generally Hadley Louise Friedland, The Wetiko Legal Principles: Cree and Anishinabek Responses to Violence and Victimization (2018).

225. See infra Appendix.

226. Id.

227. Henning, Woodrow \& Dubovec, supra note 13, at 501. 
problem the "Buckskin Curtain." 228 According to a recent report from the Center for Indian Country Development, there has not been much change in access to banking. ${ }^{229}$ In the absence of traditional forms of lending, alternatives to banking such as pay-day lenders have appeared; traditional brick and mortar banks continue to be scarce resources on tribal reservations. ${ }^{230}$ One reason is that traditional federal banks require significant capital reserves that may tie up too many resources for tribes to invest in banking. ${ }^{231}$ A second reason is the organizational capacity that banking requires due to the degree of regulatory oversight. 232

While traditional banks have not taken root in Indian Country, secondary financial institutions known as Community Development Financial Institutions ("CDFI") have somewhat filled the gap to provide lending access on Indian tribes. ${ }^{233}$ CDFIs, or combined institutions of banks or credit unions and CDFIs, comprise seventy of the financial institutions in Indian Country of the ninety-three total native-servicing financial institutions. ${ }^{234}$ Still, the lack of access to financial institutions in Indian Country is an organic condition that will shape how extensively Article 9 is used in the short term. Whether the adoption of uniform secured lending laws has the effect of luring financial institutions to tribal territories is something to be determined. Nevertheless, tribes that adopt secured lending laws set the conditions for entering the lending and banking sector on their own. The opportunity for tribes to shape the financial well-being of their members may require the tribe step into the lending gap itself. As with other areas of lending practice, the network capacity of the tribe to draw on other resources would be a crucial step toward institutionalizing lending on its own.

228. Wirtz, supra note 15 .

229. Mapping Native American Financial Institutions, CTR. FOR Indian CounTRy DEV., https://www.minneapolisfed.org/indiancountry/resources/mapping-native-banks [https://perma.cc/86N2-NBKJ].

230. Ahtone, supra note 15.

231. Banks May Not be Answer to Tribes' Woes, 60 J. Housing \& Community DeV. 14, 14 (2003).

232. Id.

233. Ahtone, supra note 15.

234. Mapping Native American Financial Institutions, supra note 229. 


\begin{tabular}{|l|l|}
\hline Institution Type & Number \\
\hline Bank & 15 \\
\hline CDFI & 61 \\
\hline Credit Union & 9 \\
\hline Credit Union/ CDFI & 6 \\
\hline Bank/ CDFI & 3 \\
\hline
\end{tabular}

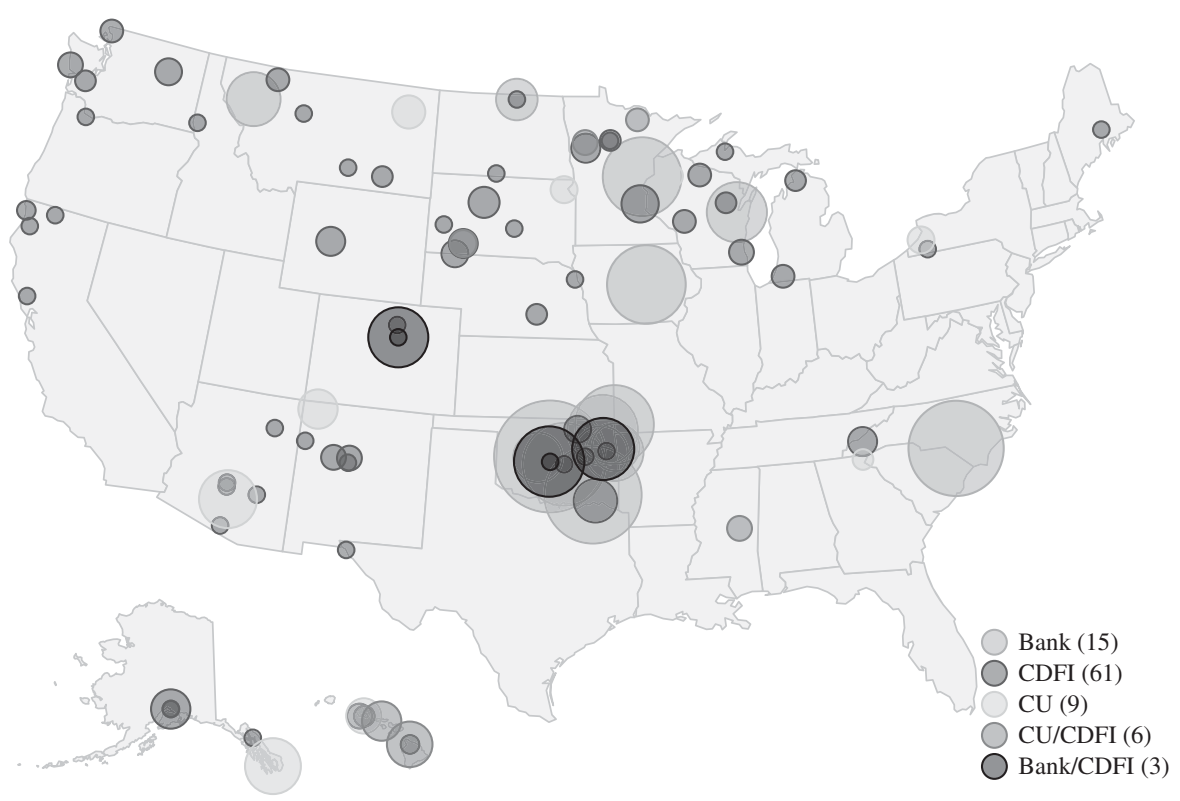

\section{CONClusion}

The creation of secured transactions laws was a bet that financial institutions would come to Indian tribes to fill the financial lending gap. Arguably, the network effects of tribal adoptions and the dearth of resources are too low at the moment to evaluate whether the formal adoptions of secured transactions laws can facilitate greater economic growth. Indian Country presents the opportunity for creative thinking for how to stimulate economic growth. Ideas, such as William Henning and Susan Woodward's nationalized filing system for Indian tribes, could help shore up insecurities that exist where tribes lack the expertise and resources to adequately facilitate a tribal filing system. ${ }^{235}$ It could also bolster the network effects that would help build institutional thickness for tribes seeking greater economic activity. As we settle into the next chapter on tribal economic growth, understanding how the laws we encourage tribes to enact interact with formal and organic resources and how they are upscaled and downscaled by 
2020] SCALING COMMERCIAL LAW IN INDIAN COUNTRY 129

tribal practice will shape whether the promise of economic growth is realized through the building of institutional thickness across borders or through localized thickness within tribal borders. 


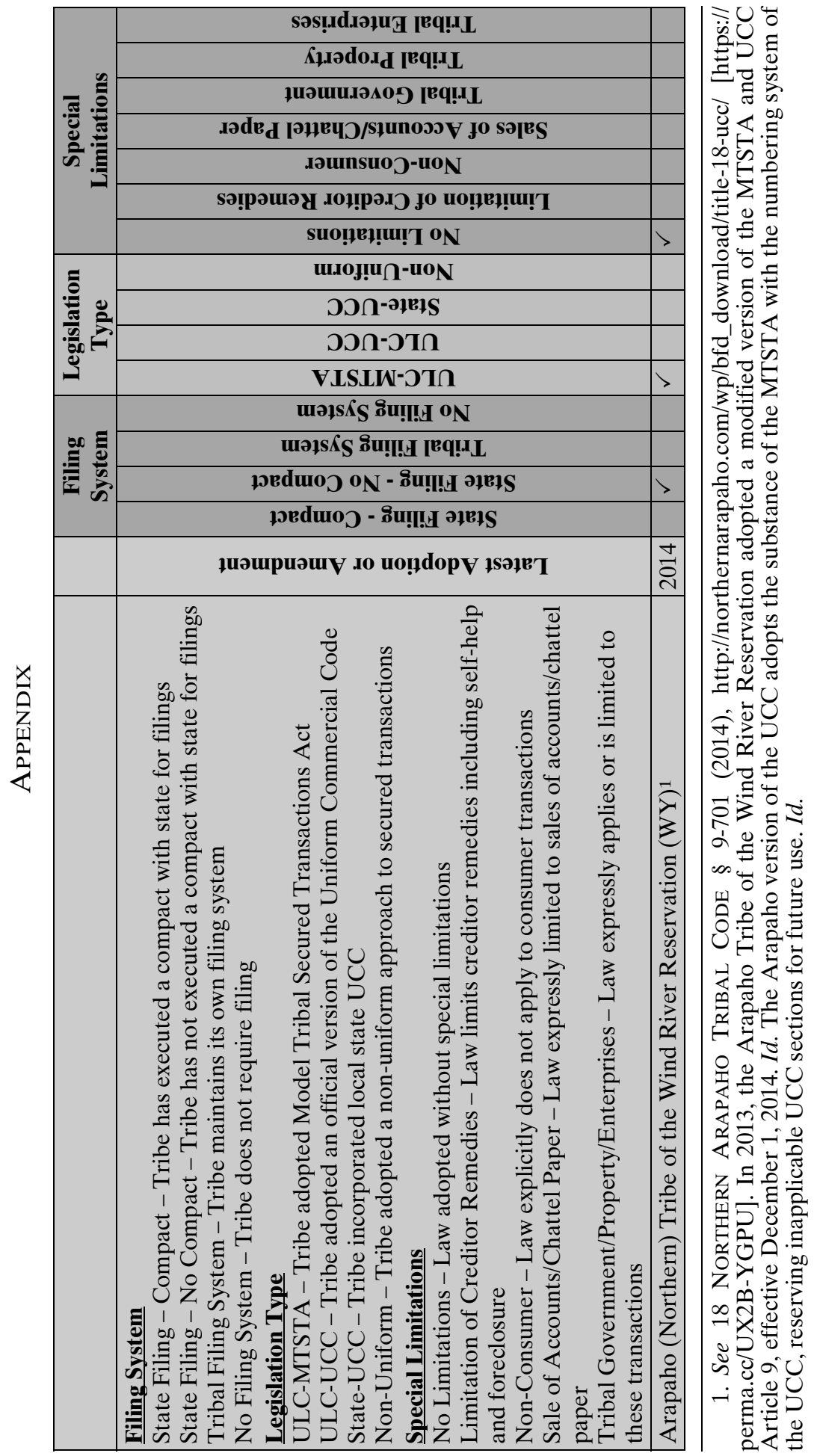




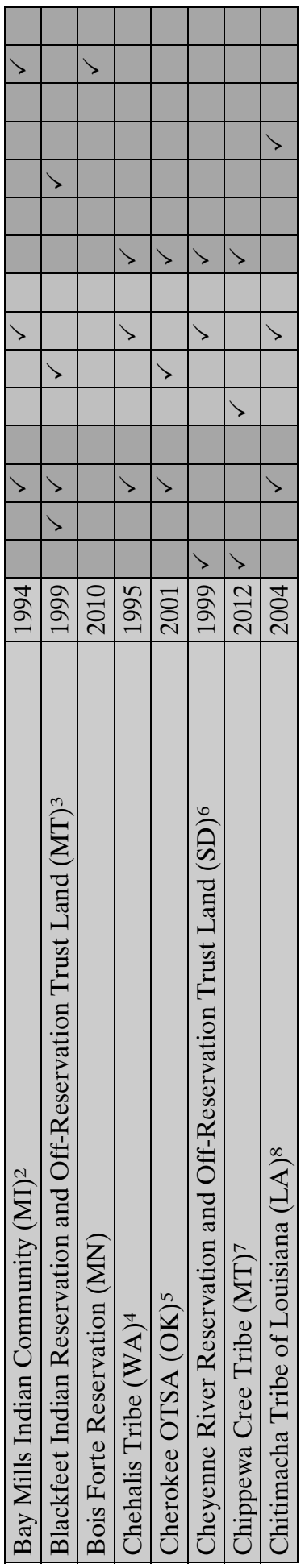

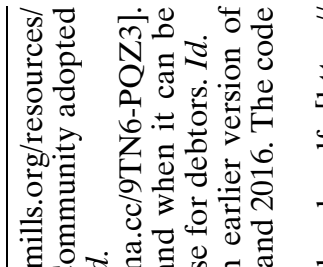

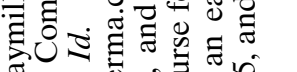

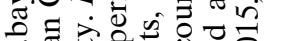

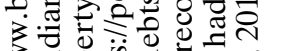

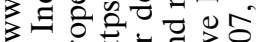

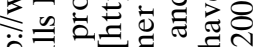

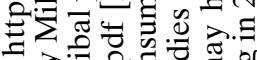

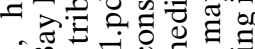

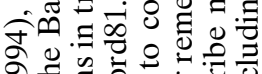

مेฏ

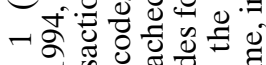

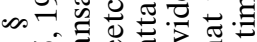

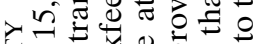

乙一்

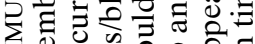

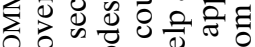

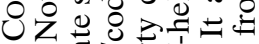

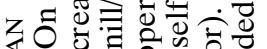

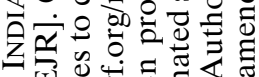

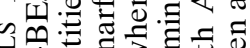

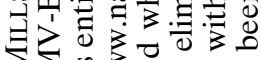

$\sum \sum .0$

خ्रे के

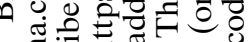

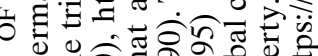

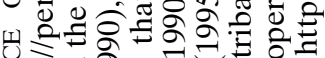

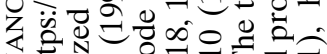

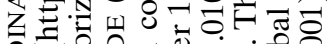
ลิษ

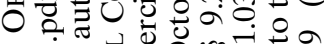

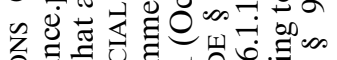

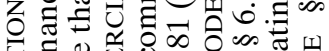
E:

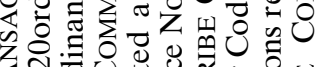

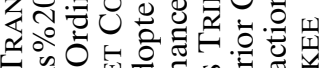

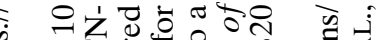

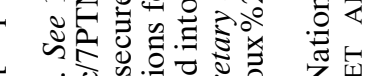

मे

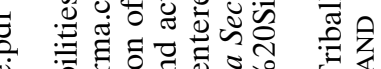

i

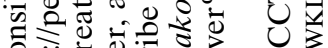

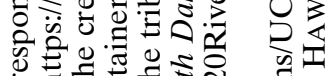

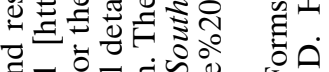

สี

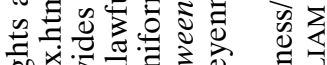

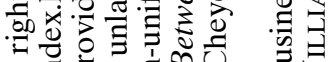

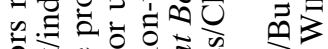

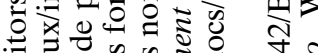

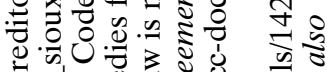

บิ

प.

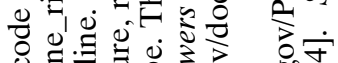

ช

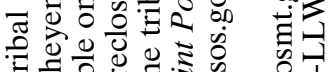

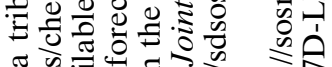

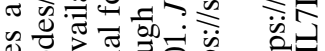

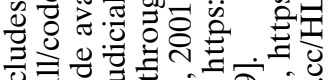

.

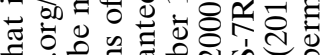

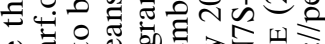

웜

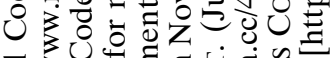

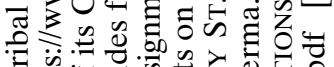

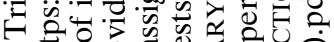

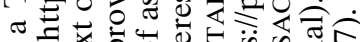

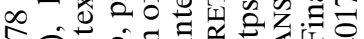

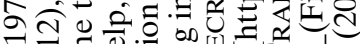

$\exists \widetilde{N} \equiv$

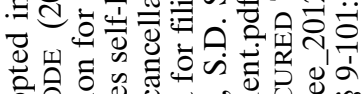
ㅇํ워

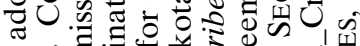

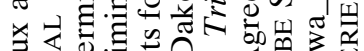
岤刍

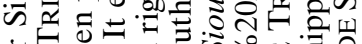

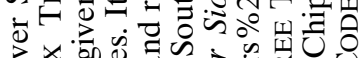
. .0 可

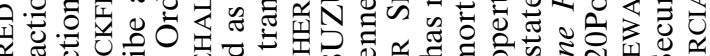

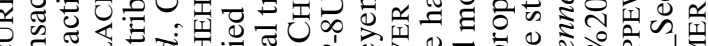

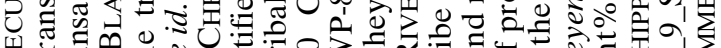

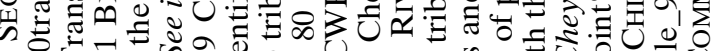
선 ๗。す

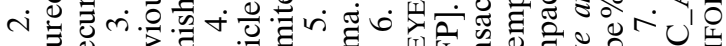

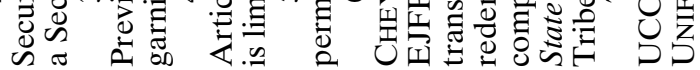


[Vol. 8

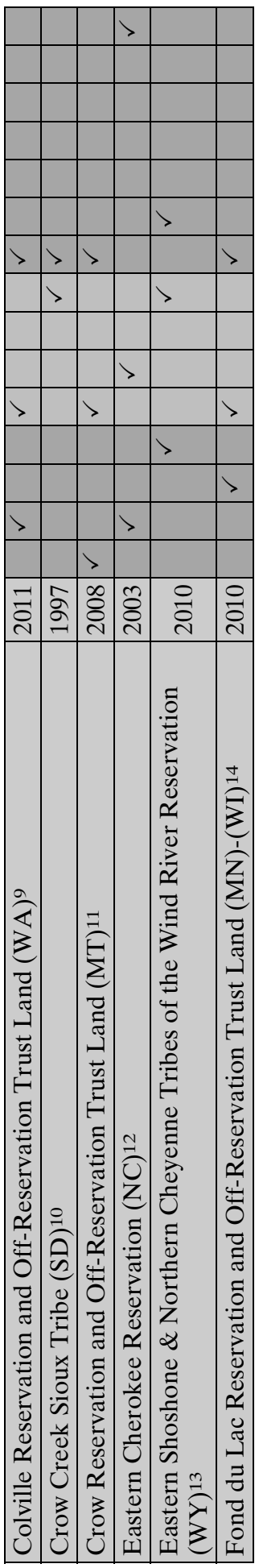

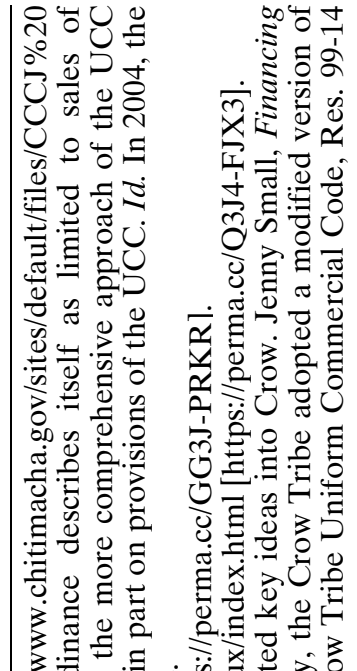

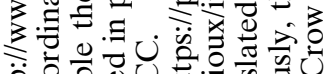

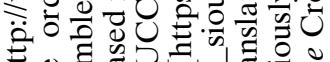

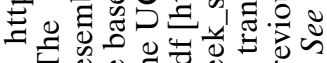
बे. จे

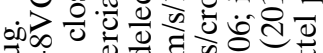

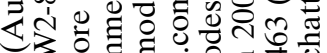

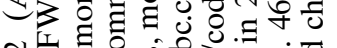

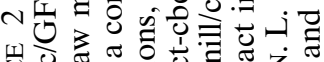
Uु

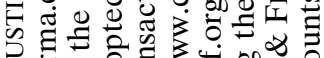

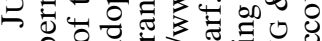

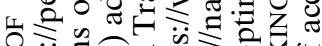
论 oิ

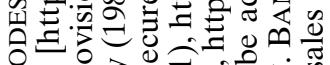
0े ๓ 舟

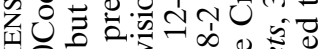

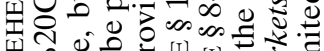

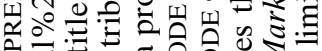
$\sum . \pi$ o 000

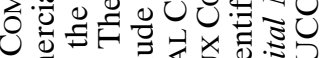

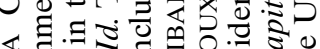

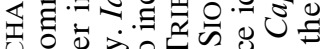
记

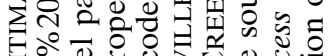

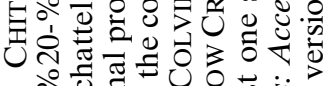

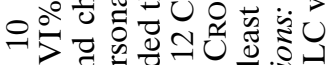

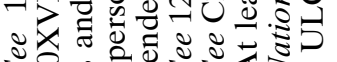
ڤั

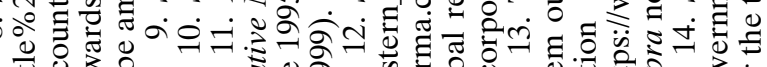

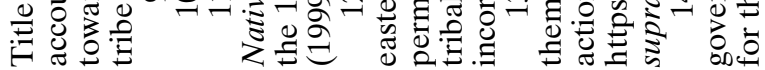




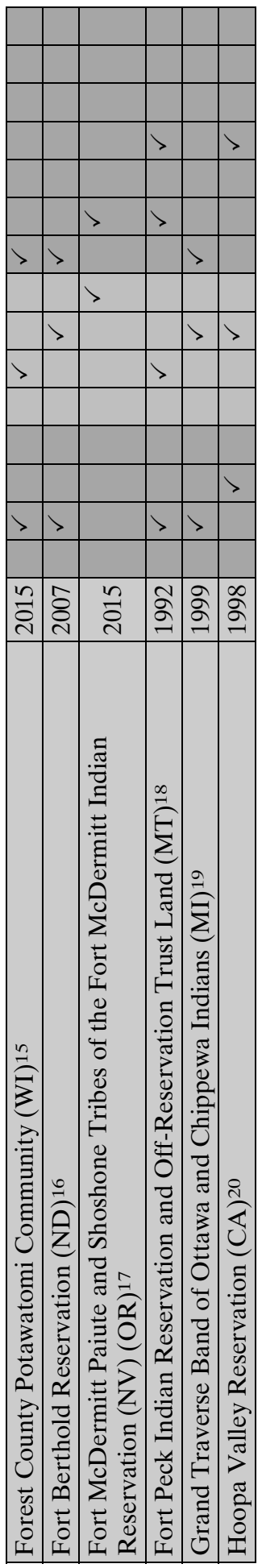

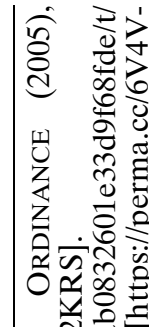

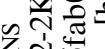

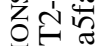

要此

艺芯远

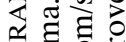

븡

ڤ

प्र

己

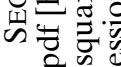

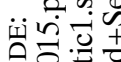

ิิ) 유유

ठํ⿺辶⿻

《官空士

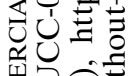

넝요

ํ่ 넌

它包总

总分是

。人

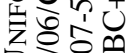

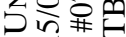

$=\bar{\circ}$ 엄

ㅇํㅁ

氹衣

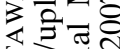

可

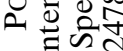

خ ن क

z

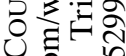

8 을

穴.

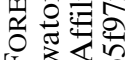

I 340

n

n่

๘ँ

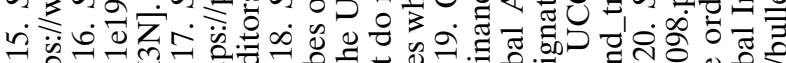
起

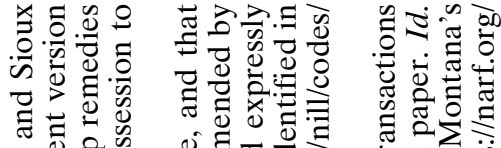

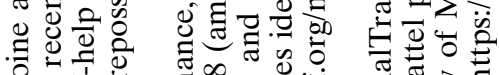

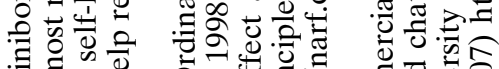

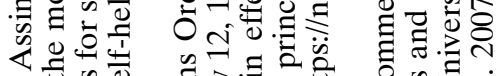

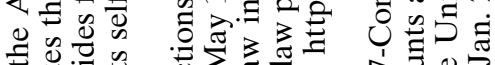

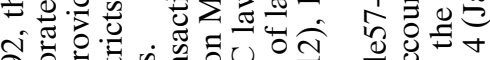
ริळ

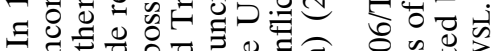

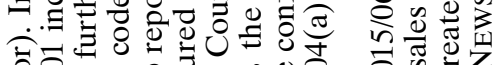

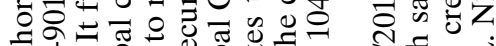

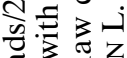
은 00,4

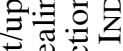

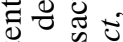

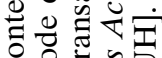

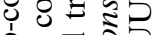

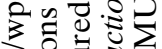
子.

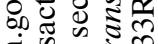

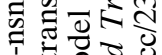

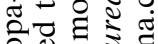
$\circ \stackrel{0}{\circ} \approx$

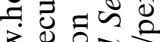

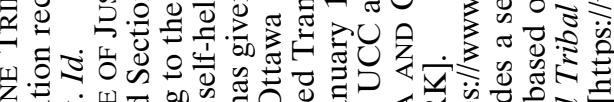

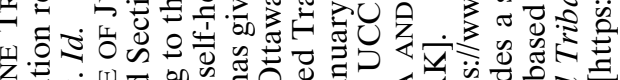

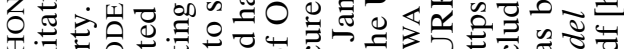

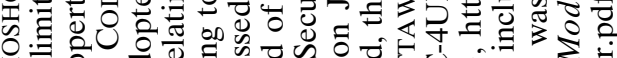

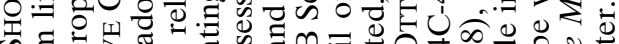
的是之

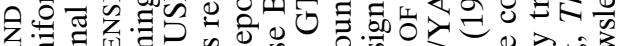

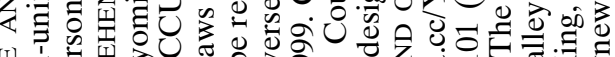

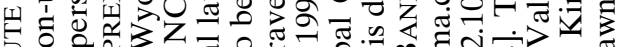

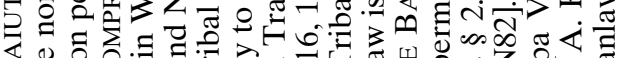

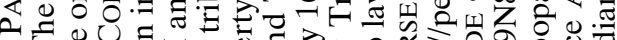

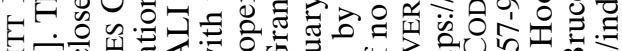

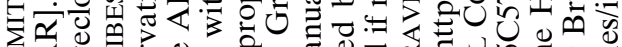

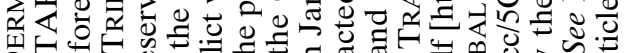

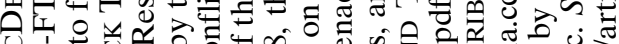
¿乙

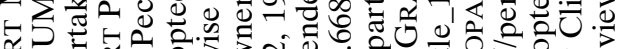

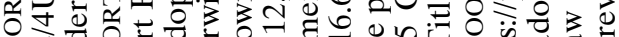

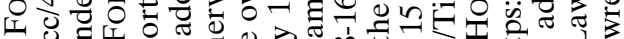

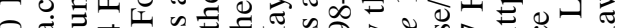

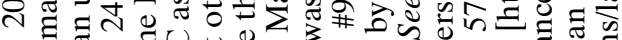

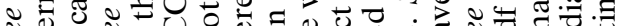




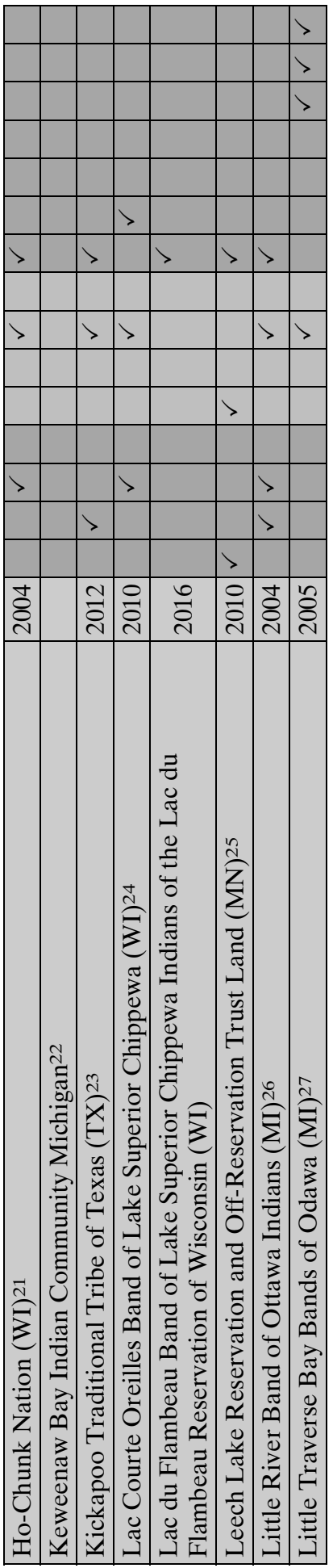

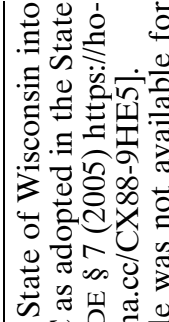

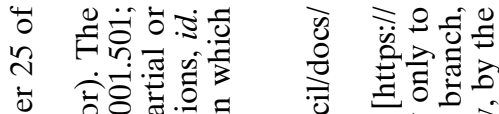

go 0 ह 융

$\exists$

可政

类

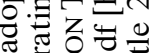

क

U 준.

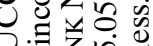

.

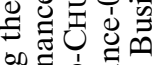

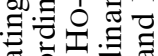

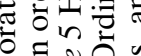

ํํㄴ

○.0

झ

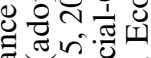

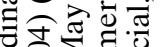

क्षे $\sum^{2}$

สิ $\infty$ o 0

可它餙

믈

ơ

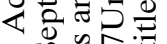

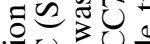

U U U

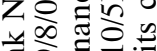

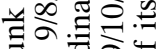

킁ㅎㅎㅎㅎㅎㅇㅇํㅇ

1.

Tे

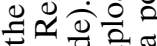

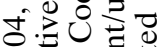

ते जٓ चै है

$\infty$ कू.

过

हn

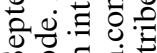

훙을 융.

प्र

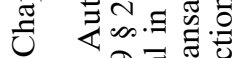

8 a

I

उ 30

을

ธี :

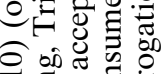

药

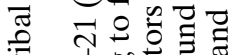

100.0 号

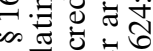

띤

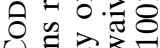

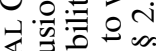

$\Rightarrow$

舀.

合苛

내을

会言总焉

$\varangle$. ज्ञ

Iิ 3

$\int^{-1}$

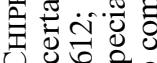

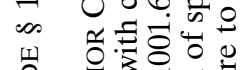

oิ

致U

य n

希 밉

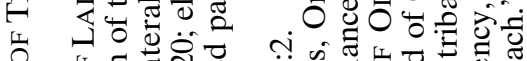

○

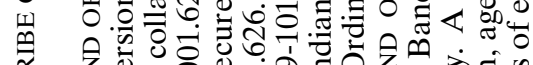

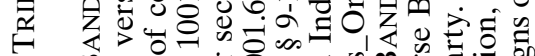

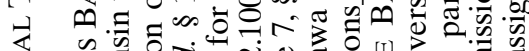

z

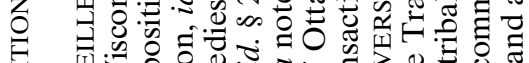

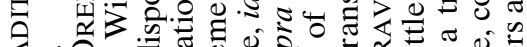

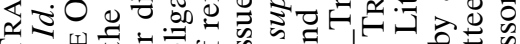

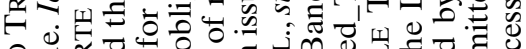

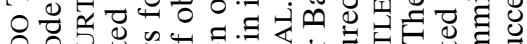

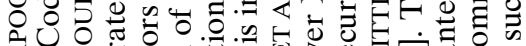

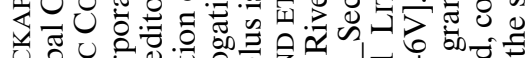

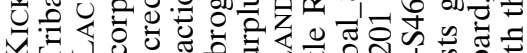

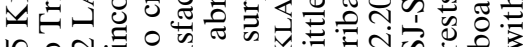

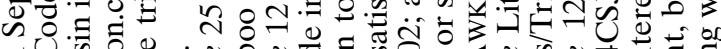
50

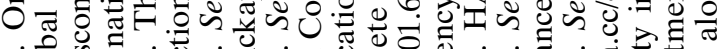
तं

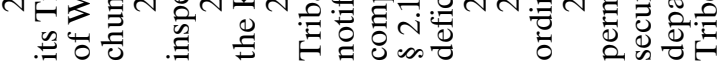




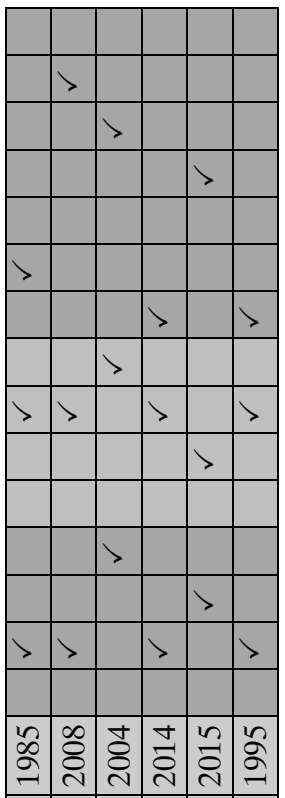

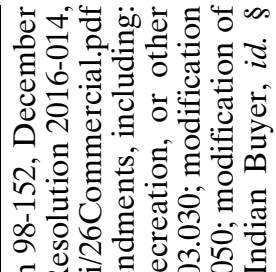

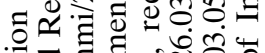

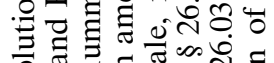

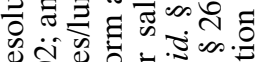

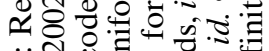

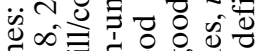

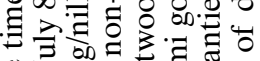
专

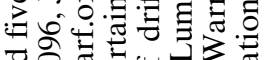

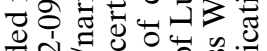

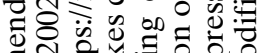
造

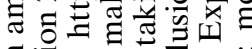

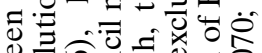

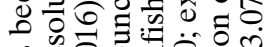

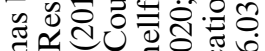

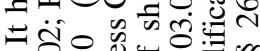
ㄷํㅇ을

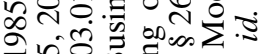
$\rightarrow-0$.

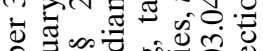

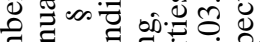

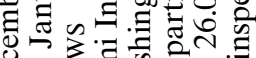
Sur

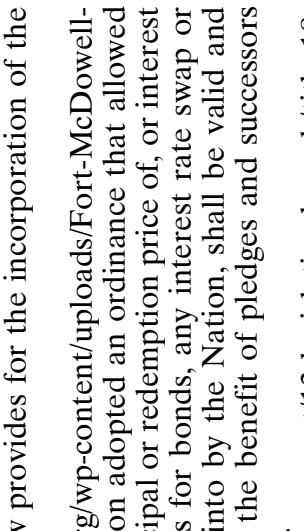

弪

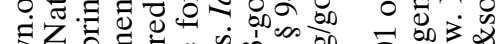

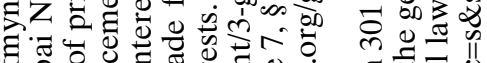

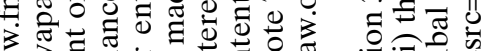

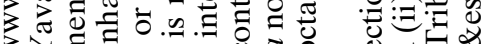

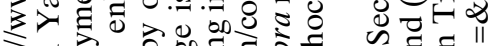

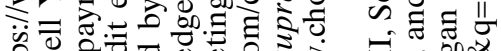

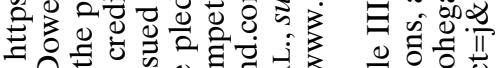

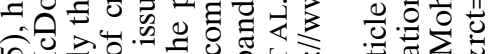

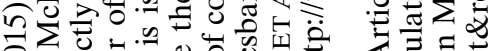
过든.

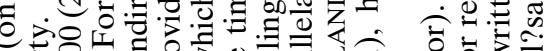

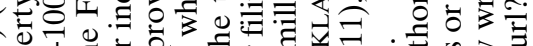

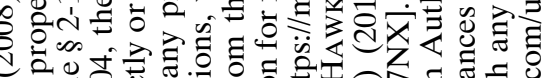
- $\pi 0$ \%

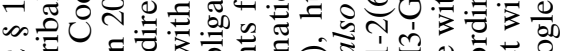

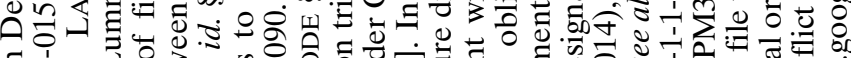
के

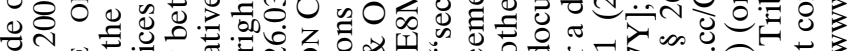
势

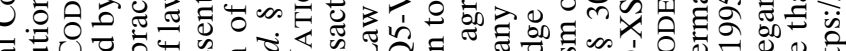
ส

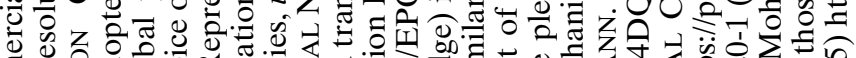

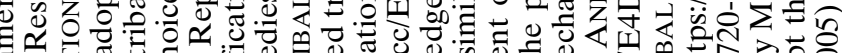

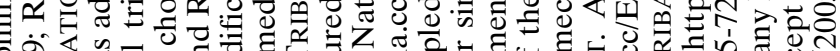

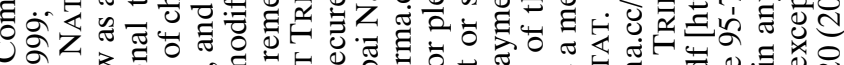
西 ơ

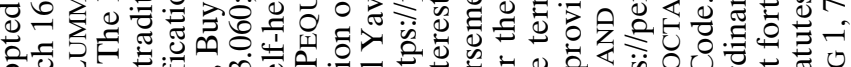

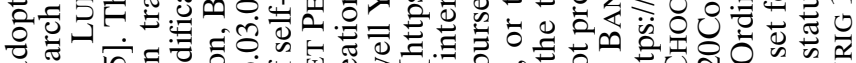

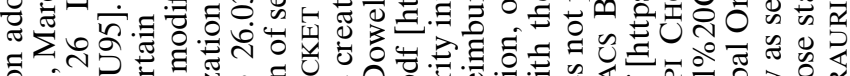

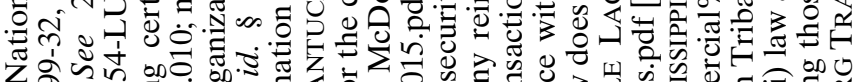
.

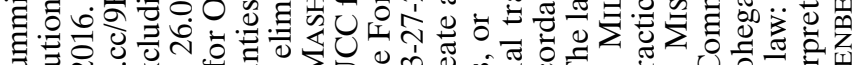

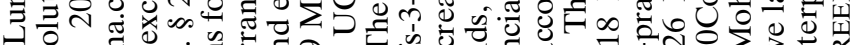

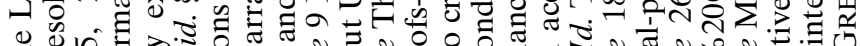

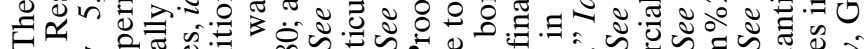
कo 施. ஸे

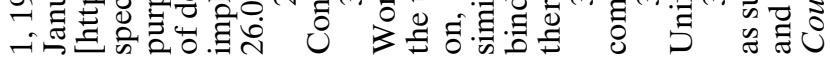


[Vol. 8
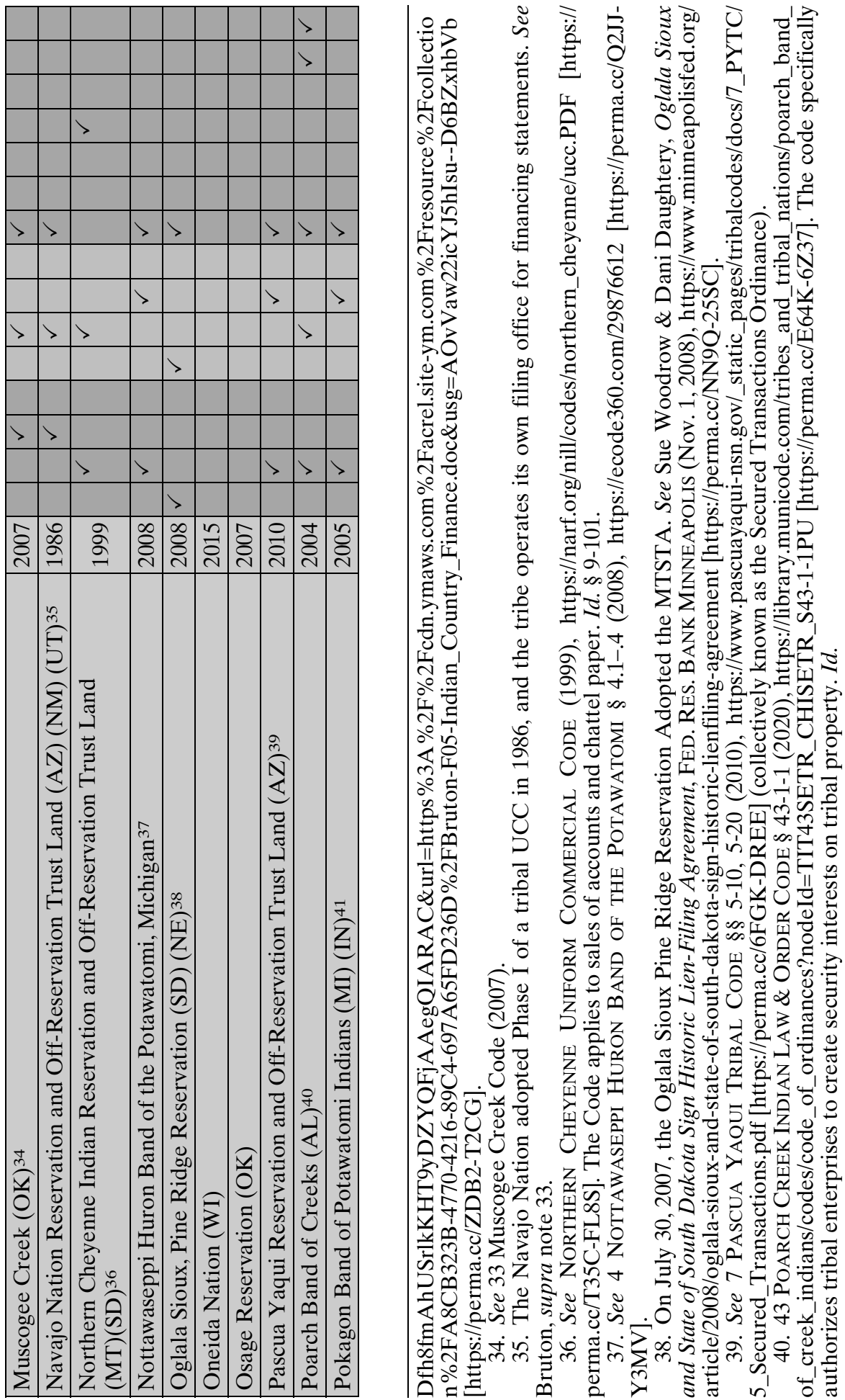


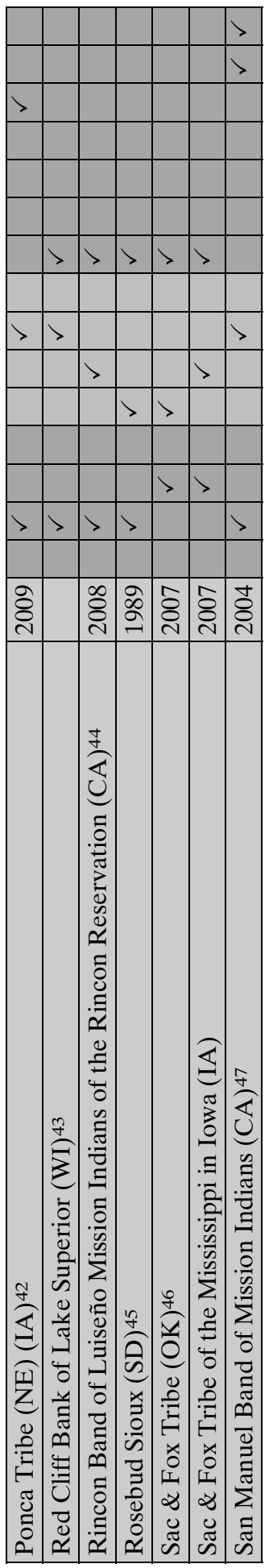

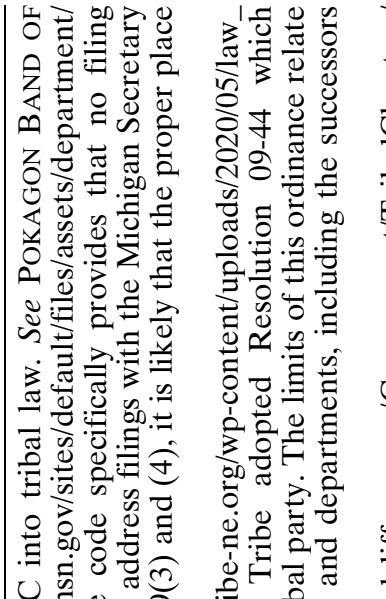

$\circlearrowright \stackrel{5}{0} \approx$

S)

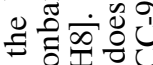

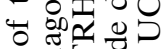

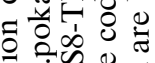

के 政定

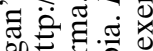
表正要

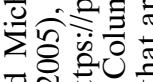
-

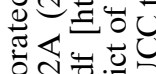

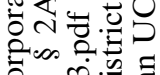

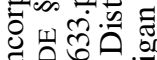

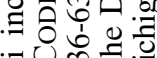

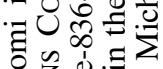
을

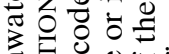
च 的.

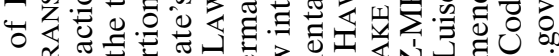
马ि

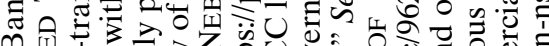

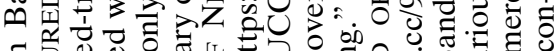

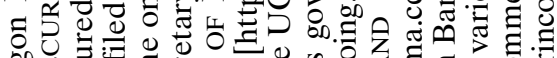

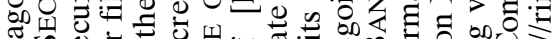

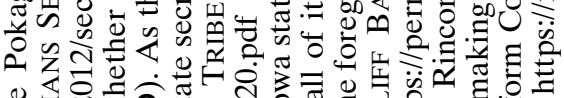

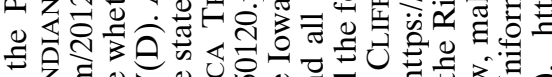

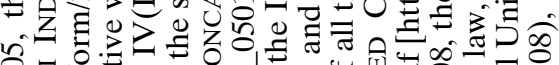

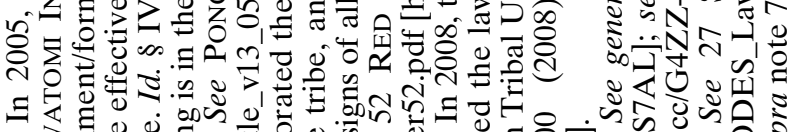

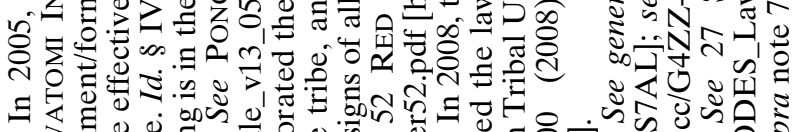
$+1$

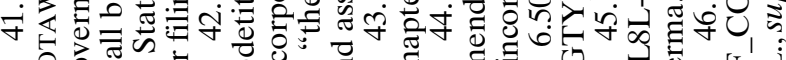

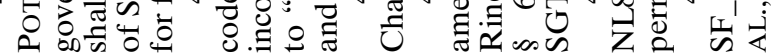


[Vol. 8
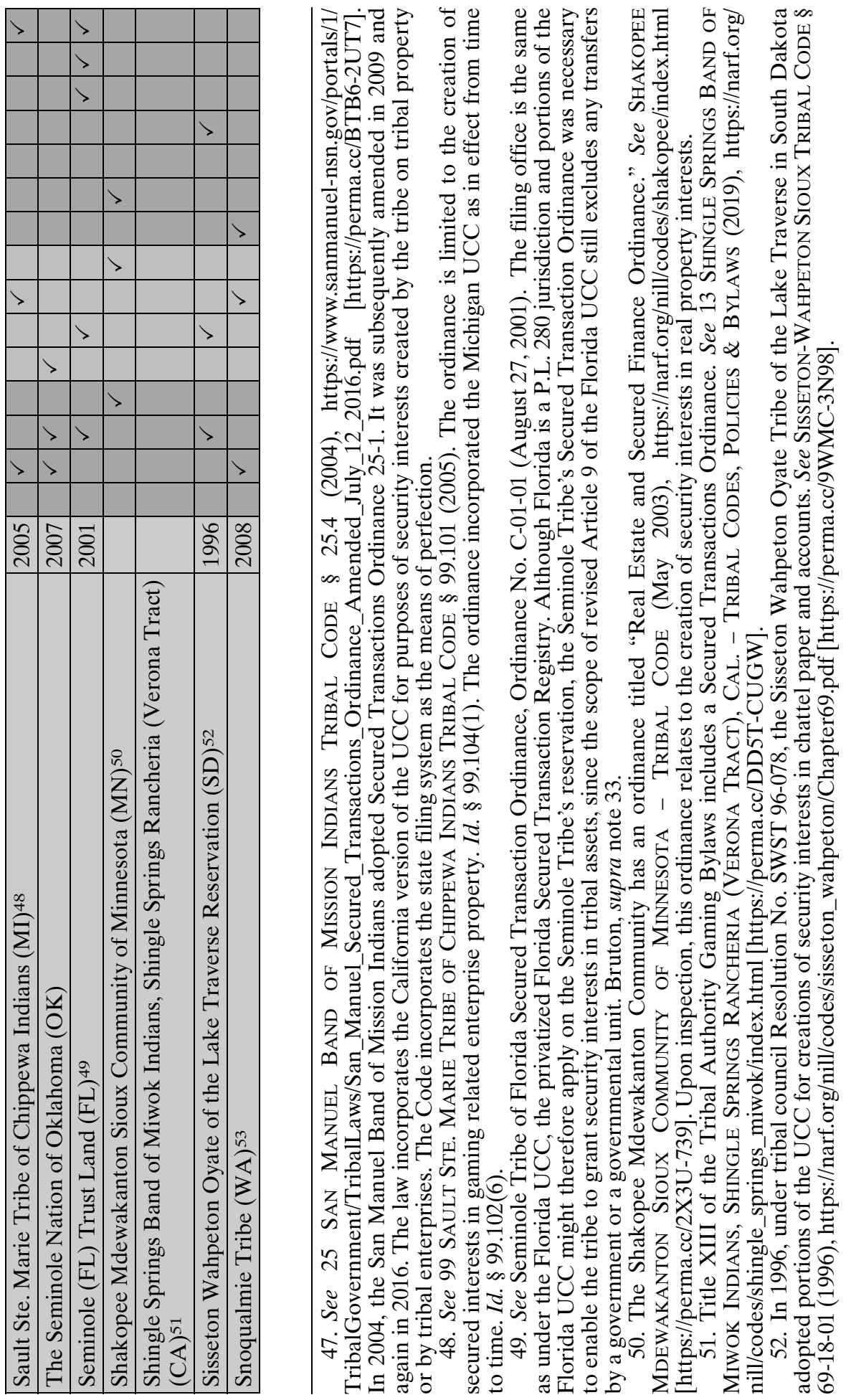

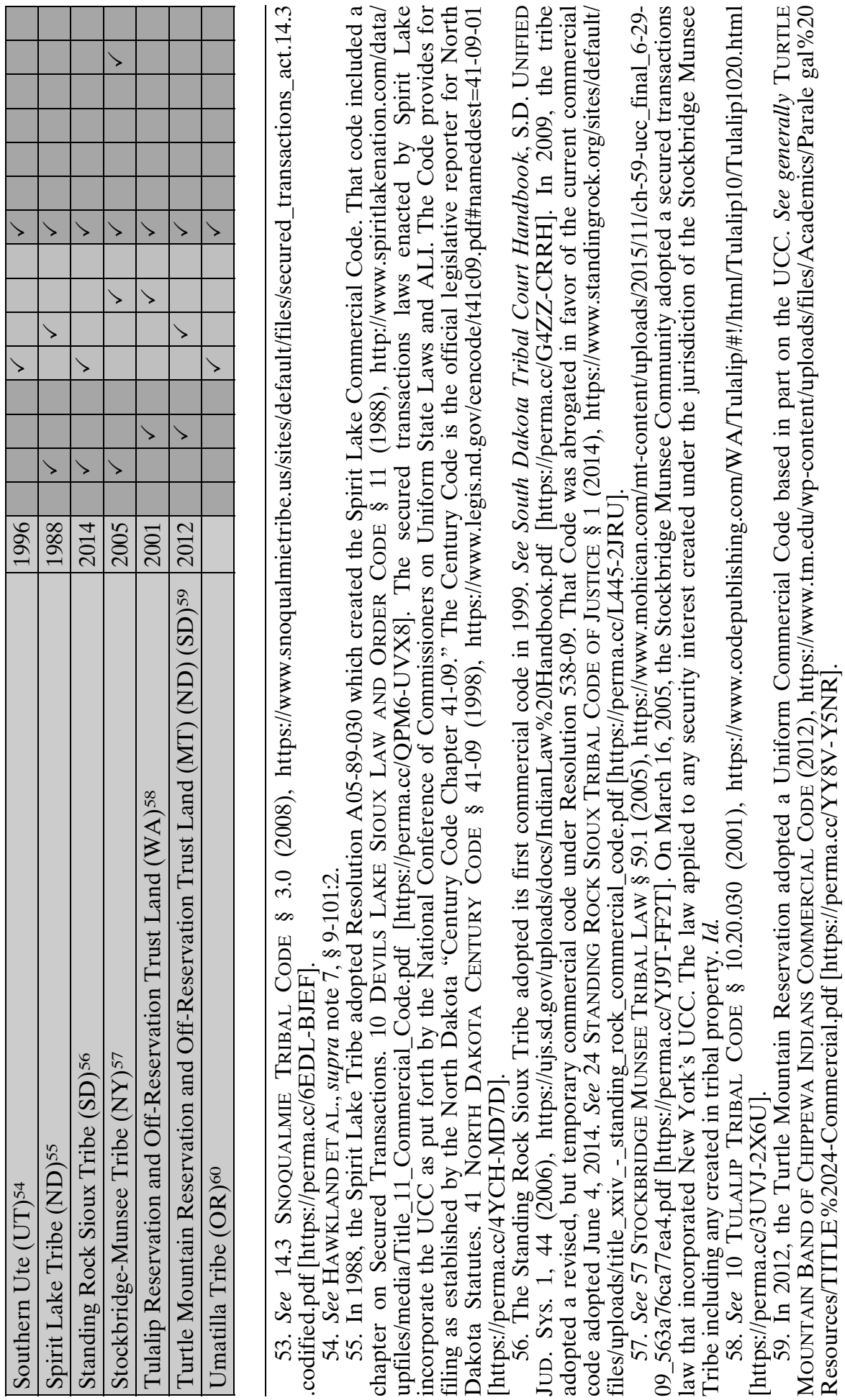
[Vol. 8
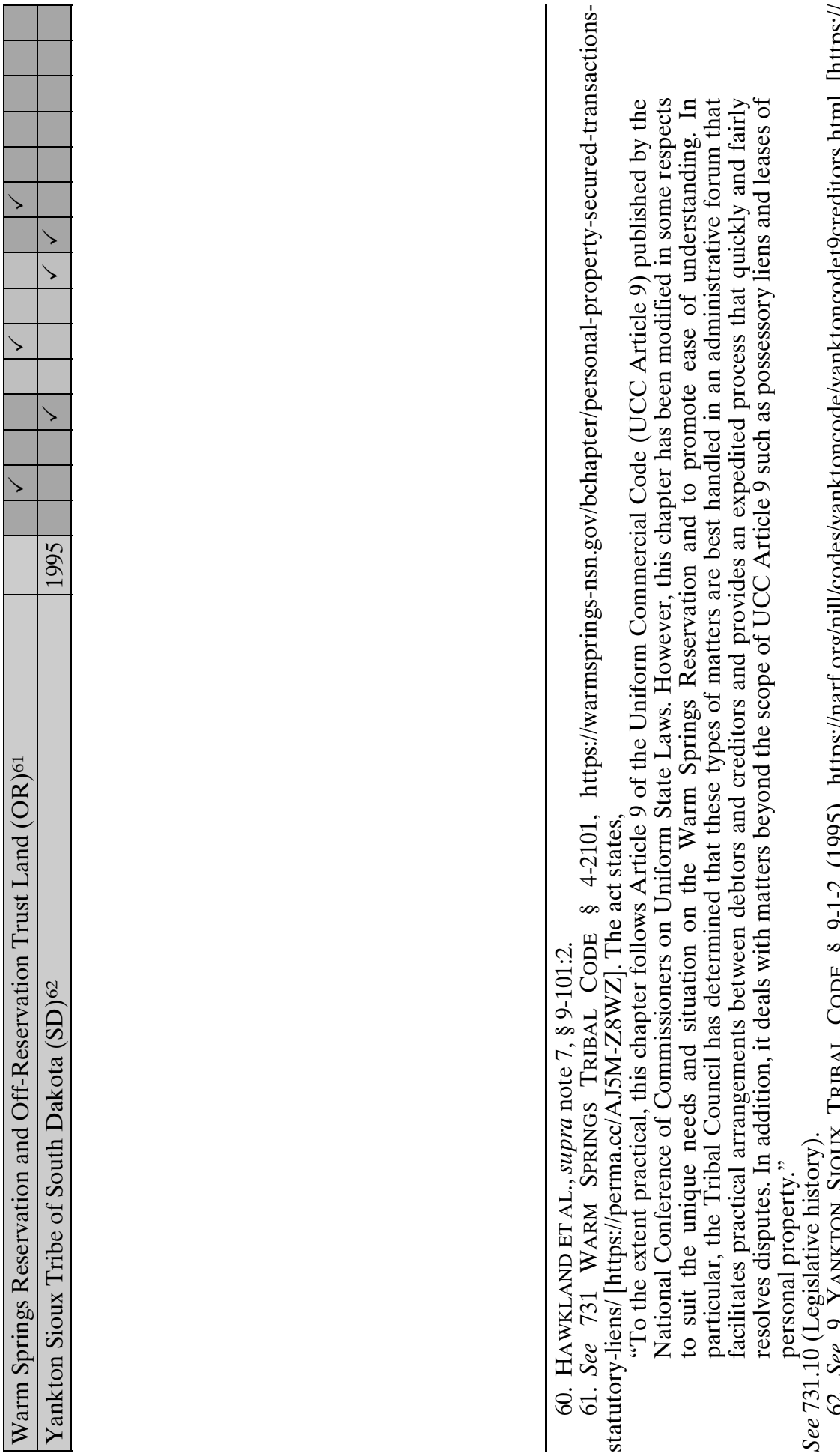

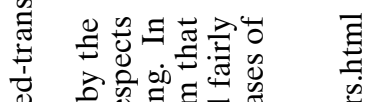

売

그를

주워

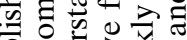

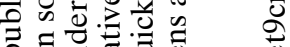

.

ㅇ

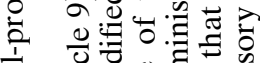

$\frac{1}{4}$

可 ญ

之

के

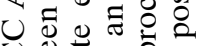

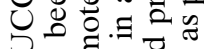

बे

골

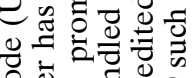

ग 0

$\frac{1}{3}$

至。

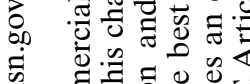

离

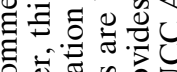

品

ㅎํ

वे ए

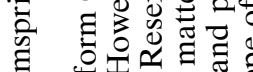

可

is

点

=

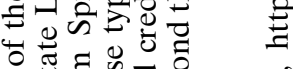

की की

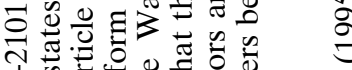

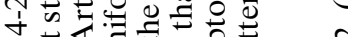

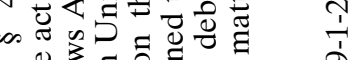

ก 떨

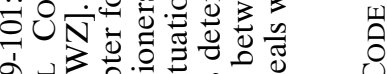

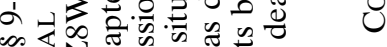

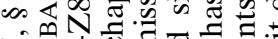

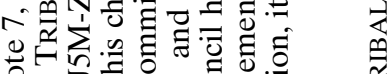

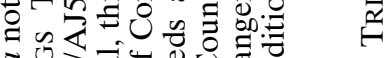

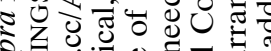

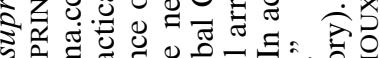

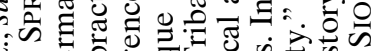

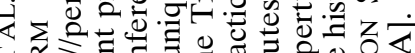

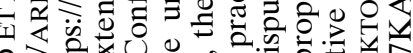

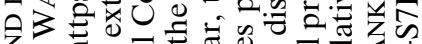

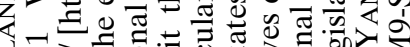
"ळ. र 0 का 结 8ंष्ञ 